\title{
Calcium Signaling and Tissue Calcification
}

\author{
Diane Proudfoot \\ Signalling Division, Babraham Institute, Babraham, Cambridge CB22 3AT, United Kingdom \\ Correspondence: diane.proudfoot@babraham.ac.uk
}

Calcification is a regulated physiological process occurring in bones and teeth. However, calcification is commonly found in soft tissues in association with aging and in a variety of diseases. Over the last two decades, it has emerged that calcification occurring in diseased arteries is not simply an inevitable build-up of insoluble precipitates of calcium phosphate. In some cases, it is an active process in which transcription factors drive conversion of vascular cells to an osteoblast or chondrocyte-like phenotype, with the subsequent production of mineralizing "matrix vesicles." Early studies of bone and cartilage calcification suggested roles for cellular calcium signaling in several of the processes involved in the regulation of bone calcification. Similarly, calcium signaling has recently been highlighted as an important component in the mechanisms regulating pathological calcification. The emerging hypothesis is that ectopic/pathological calcification occurs in tissues in which there is an imbalance in the regulatory mechanisms that actively prevent calcification. This review highlights the various ways that calcium signaling regulates tissue calcification, with a particular focus on pathological vascular calcification.

$\mathrm{C}$ alcification or mineralization are terms givto describe the crystallization of ionized calcium $\left(\mathrm{Ca}^{2+}\right)$ and $\mathrm{PO}_{4}{ }^{3-}$. This is a highly regulated physiological process occurring in bones and teeth, and a pathological process occurring in soft tissues. For calcification to initiate, a nidus for crystallization is required, along with an adequate supply of local $\mathrm{Ca}^{2+}$ and $\mathrm{PO}_{4}{ }^{3-}$. As might be expected, the systemic concentrations of $\mathrm{Ca}^{2+}$ and $\mathrm{PO}_{4}{ }^{3-}$ are tightly controlled.

Approximately $99 \%$ of total body $\mathrm{Ca}^{2+}$ and $85 \%$ of $\mathrm{PO}_{4}{ }^{3-}$ is found in bone, and this large mineral pool is under continuous turnover (e.g., via bone formation, resorption, and remodeling) regulated by numerous factors, including parathyroid hormone, thyroid hormone, calcitriol (1,25-hydroxyvitamin $\mathrm{D}_{3}$ ), prostaglandins, alu- minum, fluoride, acidification, and osteo-inductive factors (Greger 2000). The relatively minor component of $\mathrm{Ca}^{2+}$ and $\mathrm{PO}_{4}{ }^{3-}$ found outside the bone is distributed between extracellular and intracellular compartments. Approximately half of the total $\mathrm{Ca}^{2+}$ content of blood is bound to proteins, whereas the remainder circulates free or complexed to anions. Systemic $\mathrm{Ca}^{2+}$ is regarded as a hormone itself, as it can modulate the function of the parathyroid gland, the thyroid gland, the kidney, and other organs and cells via the calcium-sensing receptor (CaSR). In fact, $\mathrm{Ca}^{2+}$ can have a more generalized effect as a hormone caused by the expression of the CaSR in numerous tissues. Systemic $\mathrm{Ca}^{2+}$ and $\mathrm{PO}_{4}{ }^{3-}$ levels normally oscillate between $\sim 1 \mathrm{~mm}$ and $1.5 \mathrm{~mm}$ (Brown 1991), although it has been proposed

Editors: Geert Bultynck, Martin D. Bootman, Michael J. Berridge, and Grace E. Stutzmann

Additional Perspectives on Calcium Signaling available at www.cshperspectives.org

Copyright (C) 2019 Cold Spring Harbor Laboratory Press; all rights reserved; doi: 10.1101/cshperspect.a035303

Cite this article as Cold Spring Harb Perspect Biol 2019;11:a035303 


\section{Proudfoot}

that larger extracellular $\mathrm{Ca}^{2+}$ changes may occur in the tiny interstitial spaces between cells, particularly at sites of inflammation (Olszak et al. 2000). Many other functions of $\mathrm{Ca}^{2+}$ are related to its role as a messenger within cells. Cells maintain a low, resting cytosolic $\mathrm{Ca}^{2+}$ concentration ( $~ 70 \mathrm{~mm}$ to $100 \mathrm{nM}$ ) through the action of calcium ATPases and exchange mechanisms that sequester the ion in intracellular stores, or extrude it across the plasma membrane (Carafoli 1991; Tsien et al. 1991; Moore et al. 1993; Sucher et al. 1996; Berridge 1997). Various stimuli, including hormones, growth factors, depolarization, and mechanical activation, trigger transient increases in cytosolic $\mathrm{Ca}^{2+}$ that lead to alterations in cell activity.

The main regulators of $\mathrm{PO}_{4}{ }^{3-}$ homeostasis are parathyroid hormone, calcitriol, and peptides known as phosphatonins such as fibroblast growth factor 23 (FGF23). Interestingly, the physiological concentrations of $\mathrm{Ca}^{2+}$ and $\mathrm{PO}_{4}{ }^{3-}$ in extracellular body fluids are known as metastable, which means they are sufficiently high to induce precipitation of calcium phosphate crystals. However, as discussed in the following sections, precipitation does not usually occur in extraskeletal tissues in health because of the presence of factors that actively inhibit calcification.

\section{PHYSIOLOGICAL CALCIFICATION AND $\mathrm{Ca}^{2+}$ SIGNALING}

Physiological mineralization is precisely controlled in terms of crystal type, morphology, and orientation, and a distinct spatial relationship exists between the mineral and organic phases. Bones contain calcified material in the form of hydroxyapatite, $\left(\mathrm{Ca}_{10}\left(\mathrm{PO}_{4}\right)_{6}(\mathrm{OH})_{2}\right)$, or carbonate-substituted hydroxyapatite organized within collagen fibrils. Bone is synthesized either directly by osteoblasts (via intramembranous ossification in flat bones, such as the skull), or by hypertrophic chondrocytes in the growth plate of cartilage (in long and short bones). This mineralized cartilage precursor is then later replaced by a mineralized bone matrix. In teeth, odontoblasts orchestrate the formation of dentin, a bone-like material that is found beneath the enamel. Bone turnover is regulated by osteoclasts that resorb mineralized matrix. Mineral-depleted matrix is recalcified via osteoblastmediated bone deposition (Clarke 2008).

Osteoblasts express various $\mathrm{Ca}^{2+}$ channels including, stretch-activated, voltage-gated, storeoperated (ORAI1), and TRP (TRPV6) channels (Jørgensen et al. 1997; Hwang et al. 2012; Lieben and Carmeliet 2012; Robinson et al. 2012; Choi et al. 2018). Voltage-gated channels are thought to be particularly important in maintaining $\mathrm{Ca}^{2+}$ waves between cells after mechanical stimulation (Lieben and Carmeliet 2012). Interestingly, L-type channels predominate in osteoblasts, whereas $\mathrm{Ca}^{2+}$ entry occurs via T-type channels in osteocytes (cells embedded within bone) ( $\mathrm{Lu}$ et al. 2012). Little is known about osteoblast differentiation but it appears that $\mathrm{Ca}^{2+}$ signaling may be involved because inactivation of ORAI1 inhibits both osteoblast and osteoclast differentiation in vitro and in vivo (Robinson et al. 2012). In osteoclasts, $\mathrm{Ca}^{2+}$ oscillations, followed by sustained $\mathrm{Ca}^{2+}$ entry via TRP channels, stimulate osteoclast maturation by activating the $\mathrm{Ca}^{2+} /$ calmodulin signaling cascade and promoting the activity of NFATc1 (the nuclear factor of T cells c1) and CREB (cAMP response element-binding protein) (NegishiKoga and Takayanagi 2009). Likewise, $\mathrm{Ca}^{2+}$ entry via TRPV4 and L-type $\mathrm{Ca}^{2+}$ channels controls chondrocyte differentiation, with Sox9 being the target transcription factor activated by $\mathrm{Ca}^{2+} /$ calmodulin signaling in chondrocytes (Lieben and Carmeliet 2012). Thus, $\mathrm{Ca}^{2+}$ signaling appears to be crucial in stimulating gene expression specific for the development of the cell types involved in bone formation and turnover.

Is $\mathrm{Ca}^{2+}$ signaling involved in the process of bone crystal formation? To answer this question, we need to know exactly how calcification occurs. A proposed mechanism for crystal formation is that the initial nidus occurs in matrix vesicles. These are extracellular particles of $\sim 100 \mathrm{~nm}$ in diameter that were first described as membrane-bound vesicles that bud from the plasma membrane (Anderson 1995). More recently, they have been reported to share many similarities with exosomes, which are a product 
of the endosomal pathway (Shapiro et al. 2015). Matrix vesicles and exosomes are distinct from apoptotic bodies released from dying cells.

There are two different types of matrix vesicles produced by chondrocytes in the bone growth plate: one type that does not mineralize and another that specifically undergoes mineralization in the hypertrophic zone of the growth plate (Kirsch et al. 1997). Importantly, an intracellular $\mathrm{Ca}^{2+}$ signal is thought to alter chondrocyte gene transcription such that matrix vesicles become endowed with transport systems promoting the accumulation of $\mathrm{Ca}^{2+}$ and $\mathrm{PO}_{4}{ }^{3-}$ inside the vesicle lumen (Kirsch et al. 1997). The evidence to support the notion that a $\mathrm{Ca}^{2+}$ signal is involved originates partly from studies in which higher intracellular $\mathrm{Ca}^{2+}$ levels were detected in mature chondrocytes, compared with immature cells (Iannotti and Brighton 1989; Gunter et al. 1990) and also from studies using the chelator BAPTA to block intracellular $\mathrm{Ca}^{2+}$ elevations (Wang and Kirsch 2002; Wang et al. 2003). The "mineralization-competent" vesicles contain enhanced levels of $\mathrm{Ca}^{2+}$-binding annexins, phosphatases, $\mathrm{Na}^{+}$-dependent phosphate transporters, cholesterol, phosphatidyl serine, and a reduced level of calcificationinhibitors. In addition to effects on cell differentiation and matrix vesicle calcification potential, recent studies in osteocytes suggest that $\mathrm{Ca}^{2+}$ oscillations stimulate matrix vesicle release from cells and lead to enhanced bone formation (Morrell et al. 2018). Thus, $\mathrm{Ca}^{2+}$ signaling is thought to regulate bone formation via stimulation of matrix vesicle/exosome release, and by stimulating gene expression such that matrix vesicles/exosomes are loaded with the required proteins to orchestrate formation of the initial nidus for calcium phosphate crystal formation.

Although much evidence supports the scheme involving matrix vesicles described above, alternative hypotheses for initiation of calcium phosphate crystallization in the normal skeleton have been suggested. For example, collagen, noncollagenous proteins (such as bone sialoprotein), and lipids independently nucleate calcium phosphate crystals, because of their $\mathrm{Ca}^{2+}$-binding and hydroxyapatite-binding properties (Raggio et al. 1986; Goldberg et al. 1996; He and George 2004). Other evidence indicates that levels of potent inhibitors of bone mineralization, such as pyrophosphate, are selectively reduced, thereby allowing calcification to occur (Hessle et al. 2002). Several studies have suggested that amorphous (noncrystalline) calcium phosphate acts as a precursor for crystal formation. Amorphous calcium phosphate forms either transiently within the gap zones inside collagen fibrils or within cells (i.e., in vesicles or mitochondria) and is subsequently secreted into the collagen-rich environment of bone where it progresses to fully crystalline calcium phosphate (Lehninger 1970; Mahamid et al. 2011; Boonrungsiman et al. 2012). It is possible that all of these mechanisms contribute toward physiological bone formation, and their links to $\mathrm{Ca}^{2+}$ signaling have yet to be fully established.

\section{PATHOLOGICAL CALCIFICATION}

Pathological calcification can occur in any tissue. It occurs commonly in aging, and is often associated with blood vessels, joints, and tumors. The calcified deposits (anchored calcium phosphate crystals within extracellular matrix) are often used as a marker of disease, although the deposits themselves can be harmful by causing mechanical stress or stiffness in affected tissues and have also been associated with cell damage and inflammation. Different terms have been assigned to calcification depending on the setting for calcium phosphate crystal formation. Dystrophic calcification occurs in association with damaged cells/tissues, and metastatic calcification occurs in normal tissue in the setting of high extracellular levels of $\mathrm{Ca}^{2+}$ and $\mathrm{PO}_{4}{ }^{3-}$ (e.g., hypercalcemia); and where there is evidence for differentiation of cells into a bone-like phenotype, other terms have been used such as heterotopic ossification, metaplasia, or osteo/ chondrocytic conversion. Fully formed bone containing osteocytes and bone marrow has been detected in diseased blood vessels, although its occurrence is relatively rare (Deneke et al. 2001). Bone cells at these sites may be derived from preexisting cells within the blood vessel, driven by osteogenic morphogens (Boström et al.2011), or from circulating cells such as 


\section{Proudfoot}

osteogenic monocytes (Collin et al. 2015). Unlike physiological mineralization, the mineral found in ectopic calcification is less organized, features variable crystal sizes and shapes, and consists of calcium phosphate crystals and other calcium salts. The various forms of calciumcontaining crystals found at different locations in vivo are summarized in Table 1 . Chemical and nuclear magnetic resonance (NMR) studies revealed that the mineral of bone and calcification in blood vessels were very similar, both containing glycosaminoglycans on the surface of hydroxyapatite crystals (Duer et al. 2008). Why calcification should occur in nonskeletal tissues has gained a great deal of interest in recent years, and various stimuli and mechanisms have been proposed (Demer and Tintut 2014). The main concepts and their links with intracellular $\mathrm{Ca}^{2+}$ signaling have been highlighted in the following sections, with a particular focus on blood vessel calcification.

Blood Vessel Calcification and $\mathrm{Ca}^{2+}$ Signaling

Calcification is found at two distinct sites in the blood vessel: in the intimal layer in association with atherosclerosis and in the medial layer in association with aging, diabetes, and renal disease. The severity of calcification in coronary arteries correlates positively with cardiovascular deaths and strokes, highlighting the need to understand the mechanisms involved (Hulten et al. 2011; Otsuka et al. 2013; Cho et al. 2015; Motoyama et al. 2015). In atherosclerosis, the calcium phosphate crystals have a spotty/speckled morphology, occurring within and around ma-

Table 1. Occurrence of different types of calcium salts

\begin{tabular}{|c|c|c|}
\hline Calcium salt & Formula & Occurrence \\
\hline Hydroxyapatite & $\mathrm{Ca}_{10}\left(\mathrm{PO}_{4}\right)_{6}(\mathrm{OH})_{2}$ & $\begin{array}{l}\text { Enamel, bone, atherosclerosis, medial calcification, } \\
\text { kidney stones (Schmid et al. 1980; LeGeros 2001; } \\
\text { Barrere et al. 2006) } \\
\text { Myocardium (Pillai et al. 2017) } \\
\text { Breast tumors (Scimeca et al. 2014) }\end{array}$ \\
\hline $\begin{array}{l}\text { Octacalcium phosphate } \\
\text { (OCP) }\end{array}$ & $\mathrm{Ca}_{8} \mathrm{H}_{2}\left(\mathrm{PO}_{4}\right)_{6} 5(\mathrm{OH})_{2}$ & $\begin{array}{l}\text { Dental and urinary caliculi, joints (Cheung et al. 1997; } \\
\text { Tomazic 2001; Whelan et al. 2005; Barrere et al. 2006) }\end{array}$ \\
\hline Carbonate-apatite & $\mathrm{Ca}_{5}\left(\mathrm{PO}_{4}, \mathrm{CO}_{3}\right)_{3}(\mathrm{OH})$ & $\begin{array}{l}\text { Enamel, bone, dental caliculi, atherosclerosis, medial } \\
\text { calcification, urinary stones, soft-tissues, joints } \\
\text { (Schmid et al. 1980; LeGeros 2001; Whelan et al. } \\
\text { 2005) }\end{array}$ \\
\hline $\begin{array}{l}\text { Amorphous calcium } \\
\text { phosphate }\end{array}$ & $\mathrm{Ca}_{9}\left(\mathrm{PO}_{4}\right)_{6}$ & $\begin{array}{l}\text { Microcalcification in coronary arteries (Roijers et al. } \\
\text { 2008) } \\
\text { Aortic valve (Kim and Trump 1975) } \\
\text { Bone (Boonrungsiman et al. 2012) }\end{array}$ \\
\hline Calcium carbonate & $\mathrm{CaCO}_{3}$ & $\begin{array}{l}\text { Atherosclerosis, apoptotic bodies (in vitro) (Proudfoot } \\
\text { et al. 2000) }\end{array}$ \\
\hline $\begin{array}{l}\text { Calcium pyrophosphate } \\
\text { dehydrate (CPPD) }\end{array}$ & $\mathrm{Ca}_{2} \mathrm{P}_{2} \mathrm{O}_{7} 2 \mathrm{H}_{2} \mathrm{O}$ & Pseudogout (Cheung et al. 1997) \\
\hline Tricalcium phosphate & $(\mathrm{Ca})_{3}\left(\mathrm{PO}_{4}\right)_{2}$ & $\begin{array}{l}\text { Joints (Cheung et al. 1997; Whelan et al. 2005; Barrere } \\
\text { et al. 2006) }\end{array}$ \\
\hline $\begin{array}{l}\text { Mg-substituted tricalcium } \\
\text { phosphate }\end{array}$ & $(\mathrm{Mg}, \mathrm{Ca})_{3}\left(\mathrm{PO}_{4}\right)_{2}$ & $\begin{array}{l}\text { Arthritic cartilage, dental caliculi, salivary stones, soft } \\
\text { tissue deposits (LeGeros 2001) } \\
\text { Aorta, breast cancer (Scimeca et al. 2014) }\end{array}$ \\
\hline $\begin{array}{l}\text { Dicalcium phosphate } \\
\text { dihydrate (DCPD) } \\
\text { (brushite) }\end{array}$ & $\mathrm{CaHPO}_{4} 2 \mathrm{H}_{2} \mathrm{O}$ & $\begin{array}{l}\text { Dental caliculi, chondrocalcinosis (LeGeros 2001; } \\
\text { Barrere et al. 2006) }\end{array}$ \\
\hline Calcium oxalate & $\mathrm{CaC}_{2} \mathrm{O}_{4}$ & Kidney stones, breast cancer (Scimeca et al. 2014) \\
\hline
\end{tabular}

$\mathrm{Mg}$ and $\mathrm{Na}$ can substitute $\mathrm{Ca} . \mathrm{Cl}_{2}$ and $\mathrm{F}$ can substitute $\mathrm{OH}$. 
trix vesicles and apoptotic bodies, with crystals appearing as aggregates of nanoparticles or as needle-like sheets located near fatty deposits, inflammatory cells, and vascular smooth muscle cells (VSMCs) (Kim 1976; Shanahan et al. 1999). Calcification has been detected either within VSMCs (in mitochondria), or in matrix vesicles closely aligned with elastin fibrils that surround VSMCs (Kim 1976).

In healthy vessels, VSMCs reside in the medial layer of blood vessels and have a contractile phenotype. VSMCs have a large intracellular $\mathrm{Ca}^{2+}$ store (the sarcoplasmic reticulum [SR]) that is used to trigger contraction. However, VSMCs are not terminally differentiated and, in diseased blood vessels, they lose their contractile properties and adopt a "repair" or "synthetic" phenotype, accompanied by conversion to a cell type that expresses various bone-regulatory proteins (Tyson et al. 2003). Whether VSMCs require intracellular $\mathrm{Ca}^{2+}$ signals to trigger this phenotypic conversion is not yet known, but it coincides with a loss of expression of voltageactivated L-type $\mathrm{Ca}^{2+}$ channels and an increased expression of T-type $\mathrm{Ca}^{2+}$ channels. $\mathrm{Ca}^{2+}$ influx via voltage-gated $\mathrm{Ca}^{2+}$ channels stimulates expression of VSMC-specific contractile proteins (smooth muscle myosin heavy chain and $\alpha$-smooth muscle actin) via RhoA/Rho kinase and myocardin (Wamhoff et al. 2004). Expression of ryanodine receptors and SR ATPase isoform $2 \mathrm{a}$ are reduced in synthetic VSMCs, compared with contractile cells (House et al. 2008). Additionally, purinergic receptor expression is reduced on VSMC phenotypic change, leading to a lack of response to purinergic agonists, which would normally stimulate $\mathrm{Ca}^{2+}$ signaling in contractile VSMCs (Erlinge 1998). Thus, conversion of VSMCs to a disease phenotype leads to changes in several $\mathrm{Ca}^{2+}$ homeostatic/signaling mechanisms, which may influence their potential in regulating calcification.

\section{VSMC $\mathrm{Ca}^{2+}$ Entry and Efflux in Relation} to Calcification

Does VSMC Ca ${ }^{2+}$ signaling, or changes in $\mathrm{Ca}^{2+}$ homeostasis, influence the calcification occurring in diseased blood vessels? Clinical trials and experimental models have revealed that the calcium channel antagonists verapamil and nifedipine can reduce vascular calcification (Fleckenstein-Grün et al. 1994; Motro and Shemesh 2001; Motro et al. 2001; Chen et al. 2010). This implies that calcification may be directly inhibited by blocking $\mathrm{Ca}^{2+}$ entry into VSMCs. However, $\mathrm{Ca}^{2+}$ entry leads to a pleiotropic cellular response with many different downstream effects that may influence calcification (Orth et al. 1996). For example, effects on intracellular $\mathrm{Ca}^{2+}$ mobilization (Marche and Stepien 2000), cell differentiation, down-regulation of alkaline phosphatase (an enzyme that generates phosphate to encourage calcification), and direct effects on matrix vesicle membrane phospholipids (Chen et al. 2010). Therefore, blocking $\mathrm{Ca}^{2+}$ entry into VSMCs via voltage-gated channels may be beneficial in preventing calcification but further studies are required to establish the exact mechanisms responsible for reducing calcification.

Another group of proteins to consider are those involved in $\mathrm{Ca}^{2+}$ efflux from VSMCs; NCX1 $\left(\mathrm{Na}^{+} / \mathrm{Ca}^{2+}\right.$ exchanger), PMCA1 (plasma membrane $\mathrm{Ca}^{2+}$ ATPase), and NCKX4 $\left(\mathrm{K}^{+}\right.$-dependent $\mathrm{Na}^{+} / \mathrm{Ca}^{2+}$ exchanger), which have all be implicated in VSMC calcification (Gui et al. 2012). The evidence for their involvement is that messenger RNA (mRNA) and protein levels for these $\mathrm{Ca}^{2+}$ efflux channels were reduced in the aortic media of a murine model of calcification (Klotho null mice) and an in vitro VSMC calcification model. MicroRNAs (miRNAs) that target expression of these proteins were induced in these calcification models: miR-135a*, miR-762, miR714, and miR-712*, and inhibitors directed against these miRNAs reduced calcification. Thus, perturbation of $\mathrm{Ca}^{2+}$ efflux mechanisms altered cytosolic $\mathrm{Ca}^{2+}$ levels within VSMCs and this appeared to influence the development of calcification.

Loss of Calcification Inhibitors and Presence of Calcification Triggers

Studies in mouse knockout models have shown that vascular calcification of the medial layer of blood vessels is under the control of several inhibitors. These include matrix Gla protein 
D. Proudfoot

(MGP) (Luo et al. 1997); osteoprotegerin, a member of the tumor necrosis factor (TNF) superfamily that regulates osteoclast differentiation (Bucay et al. 1998); FGF23, a circulating factor released from bone in response to high $\mathrm{PO}_{4}{ }^{3-}$ levels to provide feedback control of $\mathrm{PO}_{4}{ }^{3-}$ concentration (Shimada et al. 2004); Klotho, a protein associated with aging that acts as a cofactor for FGF23 signaling and has a clear link with expression of $\mathrm{Ca}^{2+}$ efflux proteins, as detailed above (Kuro-o et al. 1997; Gui et al. 2012); and fetuin- $A$, a circulating protein that binds hydroxyapatite (Jahnen-Dechent et al. 1997).

In the MGP knockout mouse, large elastic arteries display extensive calcification, leading to premature death from arterial rupture. MGP contains five $\gamma$-carboxyglutamic acid (hence the name "Gla protein") residues, formed by a vitamin K-dependent modification of specific glutamic acid residues. When the Gla residue formation is inhibited with the vitamin $\mathrm{K}$ antagonist warfarin, vascular calcification is induced both in vivo and in vitro (Price et al. 1998; Schurgers et al. 2008). The Gla residues allow $\mathrm{Ca}^{2+}$ binding and hydroxyapatite binding, which may explain their inhibitory effects on calcification. The arteries of MGP knockout mice contained chondrocytes rather than VSMCs, which suggests that MGP also maintains the VSMC phenotype. This effect may be via its binding to and inactivation of bone morphogenetic protein 2 (BMP-2), a potent inducer of calcification and bone formation (Zebboudj et al. 2003). In the rare cartilage calcification disorder, Keutel syndrome, in which DNA mutations cause truncated forms of MGP, pulmonary artery calcification occurred prematurely in affected individuals (Munroe et al. 1999; Meier et al. 2001). In addition, rare monogenic disorders caused by mutations in ENPP1 in generalized arterial calcification of infancy, ABCC6 in pseudoxanthoma elasticum, and NT5E in arterial calcification and distal joint calcification clearly indicate a genetic component to the regulation of inorganic $\mathrm{PO}_{4}{ }^{3-}$ metabolism and adenosine signaling in arterial calcification (Rutsch et al. 2011).

In the intimal layer of blood vessels, loss of calcification inhibitor activity may contribute to the development of calcified deposits in atherosclerosis (Morony et al 2008; Nitschke et al 2011; Schurgers et al 2012). However, it is clear that there are many other triggers of calcification such as oxidized lipids, reactive oxygen species, inflammatory cytokines, uremic toxins, and high levels of extracellular $\mathrm{Ca}^{2+}$. The resulting calcification is thought to be caused by an imbalance of inhibitors and triggers of calcification (summarized in Fig. 1).

\section{The $\mathrm{Ca}^{2+}$-Sensing Receptor (CaSR) and Calcification}

The CaSR is a G-protein-coupled receptor that is not only involved in systemic $\mathrm{Ca}^{2+}$ homeostasis, but is also expressed by VSMCs where it has a role in regulating myogenic tone and proliferation (Ohanian et al. 2005; Li et al. 2011). In an in vitro model using VSMCs, blocking CaSR function increased vascular calcification, and calcimimetic drugs (CaSR agonists other than $\mathrm{Ca}^{2+}$ ) that increase the sensitivity of the CaSR to $\mathrm{Ca}^{2+}$ reduced calcification (Alam et al. 2009). The potent calcification-inhibitor, MGP, is thought to be expressed at higher levels in tissues where extracellular $\mathrm{Ca}^{2+}$ is high and appears to be regulated by the CaSR. Raised extracellular $\mathrm{Ca}^{2+}$ has been reported to increase MGP transcription in vitro and in vivo, possibly a critical response to prevent calcification (Farzaneh-Far et al. 2000; Mendoza et al. 2011). MGP is thought to undergo a conformational change on $\mathrm{Ca}^{2+}$ binding, increasing its affinity for hydroxyapatite. Interestingly, $\mathrm{PO}_{4}{ }^{3-}$ and $\mathrm{Mg}^{2+}$ reduced MGPs affinity for hydroxyapatite. One study suggests that although $\mathrm{Mg}^{2+}$ is an inhibitor of calcification, $\mathrm{Mg}^{2+}$ inhibited a $\mathrm{Ca}^{2+}$-induced increase in MGP expression in a chondrocyte cell line (Nakatani et al. 2006). The role of $\mathrm{Mg}^{2+}$ in calcification is still not fully understood but there is some evidence that it has a stimulatory effect on MGP expression, involving the TRPM7 channel (Montezano et al. 2010). Thus, the expression and activity of MGP may be influenced by the CaSR, TRPM7 channels, and the local ionic environment. Some of the observations regarding $\mathrm{Mg}^{2+}$ and MGP expression are conflicting and 


$\begin{array}{ll}\text { Mineral imbalance } & \text { Inflammation } \\ \uparrow \mathrm{Ca}^{2+}, \mathrm{PO}_{4}{ }^{3-} & \uparrow \text { IL-1 } \beta, \text { TNF- } \alpha \\ \downarrow \mathrm{PPi} & \end{array}$

Osteogenic differentiation $\uparrow$ Runx2, Osterix, Msx2, ALP, osteocalcin, BMP, Wnt $\downarrow$ SM22, SM-MHC, MGP

Modified lipids
$\uparrow$ oxLDL,
glycated LDL

Modified lipids

$\uparrow$ oxLDL,
Apoptosis

$\uparrow$ ER stress, caspase-3, ROS

$\downarrow \mathrm{Bcl}-2$, MGP carboxylation

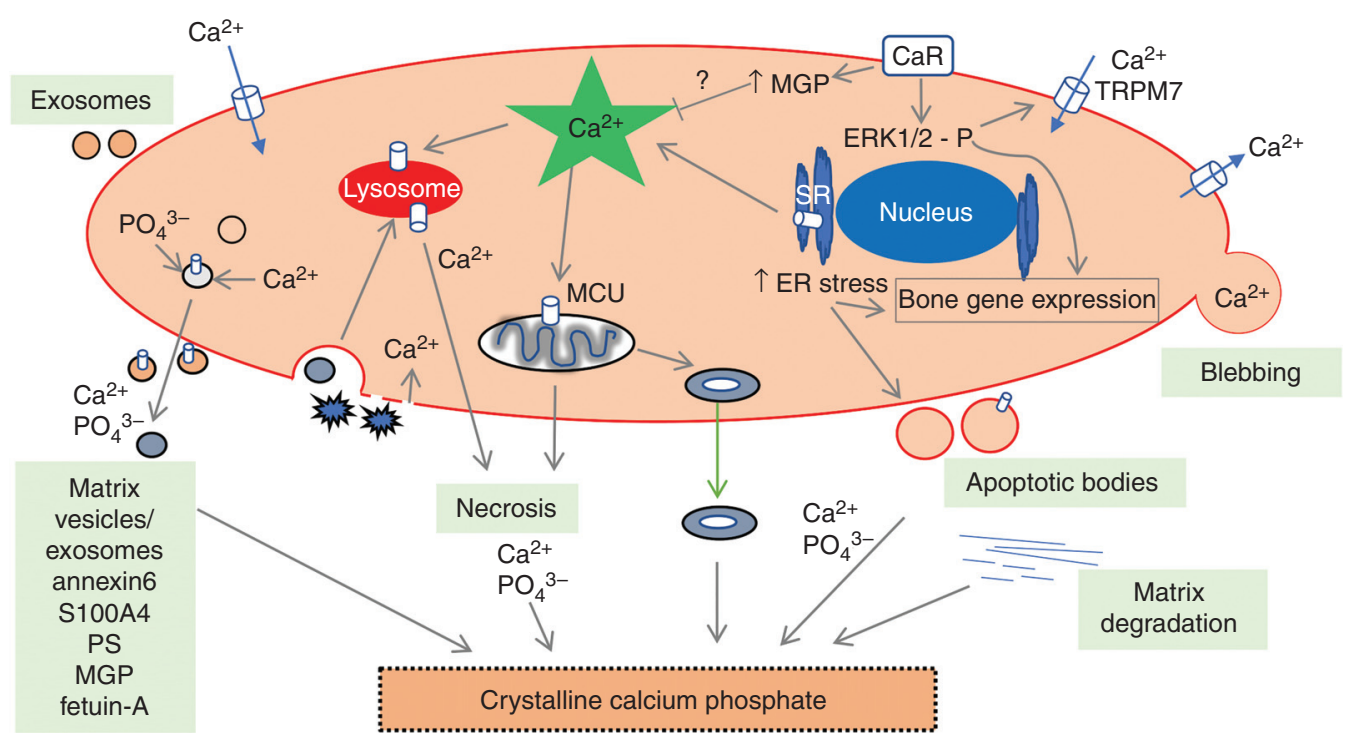

Figure 1. Summary of proposed mechanisms inducing vascular smooth muscle cell (VSMC) calcification. This figure depicts various triggers that stimulate changes in VSMC signaling, resulting in the generation of calcium phosphate crystals. VSMCs release matrix vesicles/exosomes and depending on their protein content and extracellular environment, they will nucleate calcium phosphate crystals. VSMCs undergoing apoptosis produce apoptotic bodies that can calcify in an environment that encourages calcification. Calcified mitochondria may also contribute to the generation of vesicle-derived extracellular calcium phosphate crystals. Engulfment of nanocrystals encourages cell death and inflammation, which facilitates further crystal growth. The presence of $\mathrm{Ca}^{2+}$-binding proteins in the extracellular matrix, together with matrix degradation encourages calcification of the extracellular matrix. IL, Interleukin; TNF, tumor necrosis factor; BMP, bone morphogenetic protein; MGP, matrix Gla protein; oxLDL, oxidized low-density lipoprotein; ER, endoplasmic reticulum.

this may be the result of the different models used in each study.

\section{Role for Apoptosis and Necrosis}

A link between cell death and vascular calcification has been observed in various settings: pathological studies (Kim 1995; Kockx et al. 1998); in arteries from dialysis patients (Shroff et al. 2008); in a mouse model (Clarke et al. 2010); and in human VSMCs in culture, in which apoptotic bodies were found to initiate calcification
(Proudfoot et al. 2000). Apoptotic bodies are normally efficiently removed by phagocytosis. However, in diseased blood vessels, the presence of oxidative stress, modified lipids, and the antiphagocytic molecule CD47 are thought to reduce apoptotic body clearance and can promote calcification (Anderson et al. 2002; Proudfoot et al. 2002; Kojima et al. 2016). A lack of clearance of apoptotic cells would also lead to secondary necrosis, in which $\mathrm{Ca}^{2+}$ and $\mathrm{PO}_{4}{ }^{3-}$ released from necrotic cells creates an environment favoring calcium phosphate crystal formation. 


\section{Proudfoot}

It is well established that perturbations in intracellular $\mathrm{Ca}^{2+}$ store levels or $\mathrm{Ca}^{2+}$ overload can trigger apoptosis or necrosis (Orrenius et al. 2003). Therefore, it is likely that the large variety of factors that can cause changes in VSMC Ca ${ }^{2+}$ homeostasis in diseased blood vessels could induce calcification via apoptosis, necrosis, and prevention of phagocytosis. It is worth noting here that engulfment of apoptotic bodies by phagocytic cells requires oscillatory $\mathrm{Ca}^{2+}$ signals (Melendez and Tay 2008), and these signals have been observed in human VSMCs engulfing apoptotic cells (Proudfoot and Dautova 2013). This raises the notion that in addition to professional phagocytic clearance of apoptotic cells, VSMC phagocytic capabilities may also be important in maintaining healthy, debris-free, and calcification-free blood vessels.

One of the triggers for activating apoptosis and necrosis in VSMCs is calcium phosphate crystals themselves. Studies using human VSMCs have found that crystals extracted from human calcified arteries and chemically synthesized calcium phosphate nanoparticles induced VSMC death in vitro, involving both apoptosis and necrosis (Ewence et al. 2008). Interestingly, these calcified particles stimulated a series of transient, reversible elevations in cytosolic $\mathrm{Ca}^{2+}$ in fura-2-loaded VSMCs, with each individual cell having a different pattern of $\mathrm{Ca}^{2+}$ elevations. Electron microscopy analysis revealed evidence of uptake of crystals into cells via endocytosis and also areas of plasma membrane damage soon after exposure to calcium phosphate crystals. Some cells displayed recovery to baseline cytosolic $\mathrm{Ca}^{2+}$ levels, suggesting that homeostatic mechanisms were activated. However, in cells that died, a large unrecoverable $\mathrm{Ca}^{2+} \mathrm{el}-$ evation occurred, accompanied by cell blebbing and loss of plasma membrane integrity (necrosis) (Ewence et al. 2008; Dautova et al. 2014). Evidence for repair of plasma membrane damage is that before death, blebs containing the cell-impermeant dye propidium iodide were extruded from viable cells. $\mathrm{Ca}^{2+}$ entry into cells via plasma membrane damage has been shown to activate repair via annexins and subsets of lysosomes (Reddy et al. 2001; Draeger et al. 2011). Membrane damage is therefore one way that $\mathrm{Ca}^{2+}$ can enter VSMCs leading to cytosolic $\mathrm{Ca}^{2+}$ elevations. Some of the $\mathrm{Ca}^{2+}$ increases that occurred following addition of crystals to VSMCs may have been derived from intracellular $\mathrm{Ca}^{2+}$ sources such as lysosomes, because bafilomycin A reduced the size of $\mathrm{Ca}^{2+}$ elevations and inhibited cell death (Ewence et al. 2008). Other $\mathrm{Ca}^{2+}$-storing organelles may also be involved, particularly in the generation of $\mathrm{Ca}^{2+}$ oscillations, although this possibility is yet to be fully investigated.

Fetuin-A, a calcification-inhibitor known to bind hydroxyapatite reduced $\mathrm{Ca}^{2+}$ elevations in calcium phosphate crystal-treated VSMC (Dautova et al. 2014). Fetuin-A also delayed plasma membrane damage and delayed cell death, indicating that the damaging effects of calcium phosphate crystals can potentially be reduced or blocked via a variety of mechanisms. It is also interesting to note that fetuin-A levels are lower in patients with chronic kidney disease (CKD), and these patients can have particularly severe vascular calcification. Furthermore, patients with CKD have a high vascular calcium load, deposited as nanocrystals in the extracellular matrix (Shroff et al. 2008). In a study using ex vivo human blood vessels treated with high $\mathrm{Ca}^{2+}$ and $\mathrm{PO}_{4}{ }^{3-}$, similar to levels in CKD patients, VSMCs underwent apoptosis coinciding with formation of the first calcium phosphate crystals (Shroff et al. 2010). However, more recent studies using human VSMCs suggest that if the cells survive initial calcium phosphate crystal exposure, their longer-term effects can result in stimulation of proinflammatory pathways and chemokine release (Dautova et al. 2018). Thus, calcium phosphate crystals can induce cell death and promote inflammation on exposure to human VSMCs, and cytosolic $\mathrm{Ca}^{2+}$ elevations occur before these events. Further studies are required to determine the exact nature of $\mathrm{Ca}^{2+}$ elevations induced by calcium phosphate crystals and how they are involved in triggering damaging effects in vascular cells.

\section{ER Stress and Calcification}

Disturbances in cytosolic $\mathrm{Ca}^{2+}$ homeostasis can induce endoplasmic reticulum (ER) stress 
(Krebs et al. 2015) and there are several reports that link ER stress with the development of vascular and aortic valve calcification (Cai et al. 2013; Shanahan and Furmanik 2017; Panda et al. 2018). In valvular interstitial cells (VICs) loaded with fluo-3-AM, oxidized low-density lipoprotein (oxLDL) was reported to increase intracellular $\mathrm{Ca}^{2+}$ (Cai et al. 2013). Both oxLDL and the $\mathrm{Ca}^{2+}$ ionophore, A23187 induced ER stress, whereas BAPTA-AM protected VICs from ER stress induced by A23187 or oxLDL, suggesting that ER stress was dependent on raised cytosolic $\mathrm{Ca}^{2+}$ levels. ER stress is normally relieved by the unfolded protein response (UPR), which restores ER homeostasis by reducing the aggregation and build-up of unfolded proteins. Proper functioning of the UPR is required in physiological processes, such as cartilage and bone development (Murakami et al. 2009; Saito et al. 2009), and failure of the UPR can lead to proapoptotic signaling (Szegezdi et al. 2006; Duan et al. 2009). Apoptosis may therefore be the link between raised cytosolic $\mathrm{Ca}^{2+}$, ER stress, and calcification.

\section{Mitochondrial $\mathrm{Ca}^{2+}$, Mitophagy, and Calcification}

Maintaining mitochondrial function to provide cellular energy and regulate cytosolic $\mathrm{Ca}^{2+}$ is essential for cellular physiology. Mitochondrial $\mathrm{Ca}^{2+}$ accumulation ( $\mathrm{Ca}^{2+}$ overload) can impair mitochondrial function and has been described in hypertension, hypercalcemia, and CKD (Fleckenstein-Grun et al. 1992; Shroff et al. 2008). Noncrystalline forms of calcium phosphate have been found within mitochondria of bone cells as a physiological precursor to crystal formation, and also in pathological calcification, where calcified mitochondria have been detected within VSMCs. In situations in which cells are exposed to stimuli that cause elevations in cytosolic $\mathrm{Ca}^{2+}$, such as with calcium phosphate crystals, homeostatic mechanisms rapidly return $\mathrm{Ca}^{2+}$ to resting levels and this is achieved partly by uptake into mitochondria. A sustained increase in intracellular $\mathrm{Ca}^{2+}$ is known to collapse the proton-motive potential gradient across the inner mitochondrial membrane (IMM) (Malis and Bonventre 1986), which may account for the cell death observed in VSMCs in response to calcium phosphate crystals.

Mitochondrial $\mathrm{Ca}^{2+}$ uptake occurs first by $\mathrm{Ca}^{2+}$ passing through the outer mitochondrial membrane $(\mathrm{OMM})$ via a voltage-dependent anion-selective channel (VDAC). This channel behaves as a diffusion pore that is permeable to ions and small hydrophilic metabolites (Shoshan-Barmatz et al. 2018). Ca ${ }^{2+}$ ions pass into the mitochondrial matrix through a channel known as the mitochondrial $\mathrm{Ca}^{2+}$ uniporter (MCU). The MCU is located within the IMM, and is highly selective for $\mathrm{Ca}^{2+}$ (Baughman et al. 2011; De Stefani et al. 2011). MCU oligomers form the selective pore, but they are part of a multiprotein complex composed of a large number of regulatory proteins, such as MICU1 (Mallilankaraman et al. 2012).

In an interesting study of blood vessels from healthy individuals, calcified mitochondria were observed after long-term treatment with raised extracellular levels of $\mathrm{Ca}^{2+}$ and $\mathrm{PO}_{4}{ }^{3-}$, whereas in blood vessels from patients with CKD, extensive calcification was observed extracellularly but not in mitochondria (Shroff et al. 2010). An explanation for this discrepancy is that VSMCs in CKD are phenotypically modified and release huge numbers of $\mathrm{Ca}^{2+}$-loaded vesicles, thus preventing $\mathrm{Ca}^{2+}$ overload and avoiding mitochondrial damage. If this is indeed the case, the phenotype of a cell may determine whether exposure to potentially toxic cytosolic $\mathrm{Ca}^{2+}$ levels results in mitochondrial $\mathrm{Ca}^{2+}$ uptake or rapid removal of $\mathrm{Ca}^{2+}$ via vesicle release. It is also possible that crystal formation within mitochondria may be a cell survival mechanism, otherwise large increases in mitochondrial $\mathrm{Ca}^{2+}$ may result in cell death. Very little is known about the mechanisms generating either amorphous or crystalline forms of calcium phosphate within mitochondria and whether this process is indeed preceded by large accumulations of mitochondrial $\mathrm{Ca}^{2+}$. It is tempting to speculate that cells with dysfunctional mitochondria, such as in aging and disease (e.g., atherosclerosis) are more sensitive to intramitochondrial $\mathrm{Ca}^{2+}$ accumulation, resulting in progression of amorphous to crystalline calcium phosphate. 
D. Proudfoot

Damaged and dysfunctional mitochondria are normally removed and recycled within cells via mitophagy - a process regulated by cytosolic and mitochondrial $\mathrm{Ca}^{2+}$ levels (East and Campanella 2013; Rimessi et al. 2013). It has recently been suggested that mitophagy is part of the physiological process of normal bone formation being involved in the transport of intramitochondrial amorphous calcium phosphate for delivery to the extracellular matrix (Pei et al. 2018). Thus, mitophagy appears to be crucial in the transportation of calcium phosphate crystal precursors for extracellular release in healthy physiological bone formation. However, in aging or pathological conditions, mitophagy can be disturbed leading to an altered clearance of damaged mitochondria (Safiulina et al. 2019), and studies suggest that disturbed mitophagy accelerates VSMC apoptosis and calcification (Swiader et al. 2016; Zhu et al. 2019).

\section{Role for $\mathrm{Ca}^{2+}$ in Matrix Vesicle/Exosome Release and Calcification}

As mentioned earlier, matrix vesicles/exosomes derived both from VSMCs and macrophages are one of the main mechanisms for initiation of physiological and pathological calcification (Anderson 1995; Reynolds et al. 2004; New et al. 2013). Limiting matrix vesicle/exosome levels, either via inhibition of autophagy or inhibiting exosome release has been shown to reduce calcification (Dai et al. 2013; Kapustin et al. 2015). Inhibition of exosome release has also been shown to reduce inflammatory mediator release from VSMCs (Dautova et al. 2018). As introduced earlier, it was suggested that high cytosolic $\mathrm{Ca}^{2+}$ levels can cause increased loading of $\mathrm{Ca}^{2+}$ in extracellular vesicles or blebs, as a cellular defense mechanism (Lemasters et al. 1987; Kim et al. 1999). Other more recent studies in hemopoietic cell lines and cancer cells support this concept, in which intracellular $\mathrm{Ca}^{2+}$ elevations stimulated exosome release (Savina et al. 2003; Messenger et al. 2018). Therefore, rapid $\mathrm{Ca}^{2+}$ accumulation in matrix vesicle/ exosomes and their release from the cell may be a protective mechanism that reduces intracellular $\mathrm{Ca}^{2+}$ overload. We can therefore speculate that exosome/matrix vesicle release may be an additional way that cells can avoid calcium overload by excreting $\mathrm{Ca}^{2+}$-loaded exosomes to the extracellular environment. Depending on the combination of proteins contained within the secreted vesicles, and on the extracellular environment, this will determine whether $\mathrm{Ca}^{2+}$-loaded exosomes will nucleate and support calcium phosphate crystal proliferation.

In some studies, extracellular exosomes themselves have been shown to promote $\mathrm{Ca}^{2+}$ signaling. Exosomes/matrix vesicles isolated from VSMCs treated with high levels of extracellular $\mathrm{PO}_{4}{ }^{3-}$ induced an increase in intracellular $\mathrm{Ca}^{2+}$, partially via $\mathrm{Ca}^{2+}$ release from intracellular stores (Chen et al. 2018). Furthermore, in a separate study, it was reported that exosomes specifically bound to autotaxin, a lysophospholipase, and through a series of signaling steps induced the release of $\mathrm{Ca}^{2+}$ from intracellular stores (Jethwa et al. 2016). These studies suggest that exosomes with a particular proteome signature can stimulate changes in intracellular $\mathrm{Ca}^{2+}$ signaling.

\section{$\mathrm{Ca}^{2+}$ in Aging, Senescence, and Calcification}

Calcification and aging are well recognized as risk factors for cardiovascular disease and mortality. Aging is thought to involve several different degenerative processes, including changes in $\mathrm{Ca}^{2+}$ homeostasis, oxidative stress, DNA damage, mitochondrial dysfunction, alterations in autophagy and mitophagy, and induction of an inflammatory, secretory-associated phenotype (SASP). Recent insights into aging disorders have aided our understanding of the mechanisms involved in aging. For example, specific mutations in the LNMA gene encoding the nuclear envelope protein lamin A cause premature aging in Hutchinson-Gifford progeria syndrome (HGPS), in which VSMC degeneration and calcification occur in premature atherosclerosis, leading to vascular stiffness, and heart attack or stroke usually before 20 years of age (Gonzalo et al. 2017). Prelamin A appears to accumulate in diseased and aged VSMCs and it has been suggested that lamin A can serve as a biomarker for vascular aging and disease (Rag- 
nauth et al. 2010; Liu et al. 2013; Warren et al. 2015). As mentioned earlier, Klotho null mice develop premature aging and vascular calcification, and it has recently been recognized that vitamin $\mathrm{D}$ is linked with all of the above potential mechanisms associated with aging (Berridge 2017). For example, vitamin D can improve the nuclear morphology, DNA repair, and senescence phenotype in HGPS patient-derived cells (Kreienkamp et al. 2016) and it also controls the expression of Klotho and Nrf2 (Forster et al. 2011). Indeed, it has been suggested that vitamin D works together with Klotho and Nrf2 to maintain intracellular $\mathrm{Ca}^{2+}$ and redox signaling (Berridge 2017). In the vascular calcification literature, there has been some debate about whether vitamin $\mathrm{D}$ is beneficial, because of the observations in some studies that vitamin Dinduced calcification (Fleckenstein-Grun et al. 1992), whereas in others it reduced calcification, or altered expression of calcification-regulatory proteins (Farzaneh-Far et al. 2001). The differences may simply be the result of dose-related or context-dependent effects (Shanahan et al. 2011).

Aging is often associated with diminished autophagy, and autophagy is thought to protect against vascular calcification. The role of $\mathrm{Ca}^{2+}$ signaling in autophagy is complex, as several studies have shown that $\mathrm{Ca}^{2+}$ signals can trigger autophagy; however, $\mathrm{Ca}^{2+}$ signals can also have anti-autophagic effects (Bootman et al. 2018). It is therefore interesting to note that calcium phosphate precipitates have been reported to induce autophagy in several cell types in vitro, and this is thought to be caused by exogenously introduced $\mathrm{Ca}^{2+}$ (Gao et al. 2008, 2010; Sarkar et al. 2009; Chen et al. 2012, 2014). Whether autophagy is stimulated by exposure to calcium phosphate crystals in a physiological or pathological setting in vivo is yet to be established. Studies using calcium phosphate nanoparticles as a vehicle to deliver biomolecules into cells in vivo would suggest that the calcium phosphate component of the complexed particles is relatively inert (Frede et al. 2017). This concept is supported by studies of endogenous calcium phosphate nanoparticles occurring in the gastrointestinal tract, where these particles are thought to be rap- idly cleared by cells in a "silent" manner (Pele et al. 2017). However, as described earlier, studies in vascular cells and in blood vessels suggest that calcium phosphate crystals are damaging to surrounding cells (Vengrenyuk et al. 2006; Ewence et al. 2008; Dautova et al. 2014; Hutcheson et al. 2014). The impact of nano- and microparticulate crystals on cells is therefore likely to depend on the type of biomolecules bound to the crystals, the target cell phenotype, and the microenvironment. If calcium phosphate crystals do indeed stimulate autophagy in vivo, this would be expected to have a favorable effect in preventing soft tissue calcification. Evidence suggests that autophagy is a protective homeostatic mechanism in normal cartilage and bone, and its reduced function in aging is associated with cell death and osteoarthritis (Settembre et al. 2008; Caramés et al. 2010; Hocking et al. 2012). In vascular cells exposed to high extracellular $\mathrm{PO}_{4}{ }^{3-}$ levels, autophagy was reported to be protective against calcification, and this effect was thought to be partly mediated via reduced matrix vesicle release (Dai et al. 2013). The link between autophagy and exosome biogenesis has been described in various cell types (Fader and Colombo 2006; Xu et al. 2018).

Matrix vesicle/exosome generation depends on both extracellular and intracellular $\mathrm{Ca}^{2+}$ levels (Kapustin et al. 2011, 2015). A recent report suggests that vesicles released by senescent endothelial cells or vesicles isolated from the plasma of elderly individuals contained higher amounts of $\mathrm{Ca}^{2+}$ and were able to induce VSMC calcification in vitro (Alique et al. 2017). These studies suggest that aging and triggers of cellular senescence alter cellular $\mathrm{Ca}^{2+}$ homeostasis such that matrix vesicles/exosomes are particularly prone to calcify and promote further calcification.

\section{Calcification in Other Tissues}

Heart valve calcification is associated with an increased mortality risk and shares similar mechanisms with arterial calcification. Its development involves osteo/chondrocytic conversion of valve interstitial cells, inflammation, cell death, and mineralized matrix vesicles (Lerman 


\section{Proudfoot}

et al. 2015). Calcification of the heart muscle (myocardium) is often associated with sites of damaged, infarcted tissue, and was thought to be driven by dystrophic mechanisms alone. However, recently a role for cardiac fibroblasts has been implicated in driving calcification via adoption of an osteoblast-like phenotype (Pillai et al. 2017).

In osteoarthritic joints, two different types of calcium phosphate crystals have been described: (1) basic calcium phosphate (BCP), which is a mixture of hydroxyapatite and octacalcium phosphate (OCP), and (2) calcium pyrophosphate dihydrate (CPPD). The formation of CPPD and BCP crystals in articular cartilage is not completely understood, but is thought to be caused by aging, injury, or genetic predisposition. Chondrocyte matrix vesicles generated either CPPD or BCP in vitro, suggesting that matrix vesicles may initiate crystal formation in joints (Derfus 1992). Other potential triggers of CPPD formation are excess quantities of extracellular ATP that could arise via cell injury or cell death (Ryan et al. 1992), or the ATP metabolite pyrophosphate ( $\mathrm{PPi}$, the anionic component of CPPD crystals [Ryan et al. 1981]). PPi is generated from exogenous ATP by a variety of ectoenzymes, and complexes with local $\mathrm{Ca}^{2+}$ to form CPPD crystals (Costello et al. 2011). When phosphate, rather than $\mathrm{PPi}$, predominates, $\mathrm{BCP}$ mineral is generated. Abnormalities of the extracellular matrix, characterized by increased levels of osteopontin and high activities of the protein cross-linking trans-glutaminase enzymes also contribute to CPPD crystal formation. Thus, in joints, it appears that calcium deposits can arise via phenotypically altered cells producing calcifying matrix vesicles and also by altered levels of local ions and proteins.

Calcium oxalate is the main type of crystal found in kidney stones and is thought to form as a result of supersaturation of soluble salts. In the kidney, cell injury is thought to cause mitochondrial $\mathrm{Ca}^{2+}$ overload and calcification (Ganote et al. 1975), whereas extracellular renal calcification occurs in cytoplasmic buds from renal epithelial cells known as ovoid bodies. Calcium phosphate crystal deposits are also common in tumors, and interestingly bone gene expression by cancer cells has been reported (Castronovo and Bellahcene 1998; Scimeca et al. 2014). In the brain, some studies suggest mutations in PDGFB, SLC20A2 (encoding the $\mathrm{Na}^{+}$-dependent phosphate transporter, Pit2), and CaSR genes are responsible for initiation and progression of calcification (Wang et al. 2012; DeMeo et al. 2018). Finally, fibrodysplasia ossificans progressiva (FOP) is a rare and debilitating condition in which calcification occurs in skeletal muscle, tendons, and ligaments exposed to injury, and is caused by mutations in the BMP type 1 receptor family member ACVR1, which leads to activation and enhancement of BMP receptor signaling (Kaplan et al. 2009).

\section{CONCLUDING REMARKS}

The events leading to the initial nidus for calcium crystal formation at the various sites of ectopic calcification are not completely understood and are likely to involve more than one mechanism, such as alteration of cell phenotype and production of calcification-stimulating factors, cell injury, and death via apoptosis or necrosis, initiation within cells (particularly mitochondria), and initiation in matrix vesicles and apoptotic bodies, where $\mathrm{Ca}^{2+}, \mathrm{PO}_{4}{ }^{3-}$, and other ion concentrations are raised above physiological levels and where calcification-inhibitors are inactive, absent, or limiting. Some of these mechanisms of calcium phosphate crystal formation in disease are shared with physiological bone formation. Changes in cytosolic $\mathrm{Ca}^{2+}$ levels within cells appear to be key in orchestrating signaling pathways that lead to physiological and pathological calcification (overview in Fig. 2). However, we still know very little of the exact nature, timing, and factors regulating $\mathrm{Ca}^{2+}$ signals during the calcification process. From currently available evidence, it appears that homeostatic mechanisms controlling normal intracellular $\mathrm{Ca}^{2+}$ signals within cells are required to maintain healthy, calcification-free tissues and that specific intracellular $\mathrm{Ca}^{2+}$ signals are a prerequisite for calcium deposition in association with disease. Although calcification was regarded as an inevitable, degenerative part of aging, it is promising that we are beginning to 


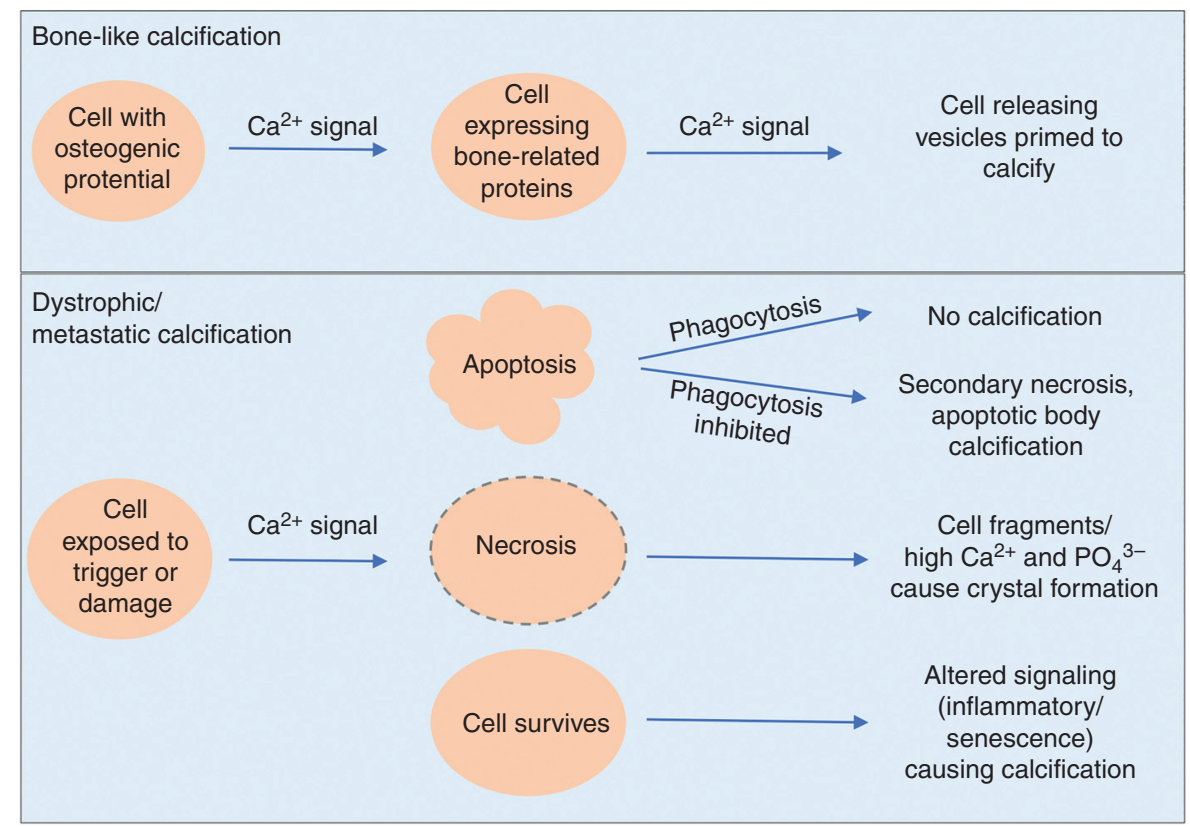

Figure 2. Schematic displaying the roles of cytosolic $\mathrm{Ca}^{2+}$ in calcification. In bone, $\mathrm{Ca}^{2+}$ signals are required for differentiation of precursor cells into specialized bone-regulatory cells. Further signals are required for release of calcification-competent matrix vesicles/exosomes. In dystrophic or metastatic calcification, cytosolic $\mathrm{Ca}^{2+}$ elevations occur before apoptosis, necrosis, and altered inflammatory/senescence signaling. Depending on the local environment, if phagocytosis is allowed to progress efficiently, apoptosis has no impact on calcification. Whereas impairment of phagocytosis allows apoptotic bodies to calcify and secondary necrosis to occur, generating increased local $\mathrm{Ca}^{2+}$ and $\mathrm{PO}_{4}{ }^{3-}$ and nidi for calcification.

understand the various ways that the initiation and progression of calcification are regulated. Hopefully, a fuller picture of how intracellular $\mathrm{Ca}^{2+}$ changes control tissue calcification will emerge in future studies.

\section{ACKNOWLEDGMENTS}

I thank Dr. Martin Bootman for his advice and collaboration on calcium signaling in vascular cells, and Prof. Catherine Shanahan for ongoing discussions on mechanisms of calcification. I also thank the British Heart Foundation and the Biotechnology and Biological Sciences Research Council (BBSRC) for support.

\section{REFERENCES}

Alam MU, Kirton JP, Wilkinson FL, Towers E, Sinha S, Rouhi M, Vizard TN, Sage AP, Martin D, Ward DT, et al. 2009. Calcification is associated with loss of functional calcium-sensing receptor in vascular smooth muscle cells. Cardiovasc Res 81: 260-268. doi:10.1093/cvr/cvn279

Alique M, Ruíz-Torres MP, Bodega G, Noci MV, Troyano N, Bohórquez L, Luna C, Luque R, Carmona A, Carracedo J, et al. 2017. Microvesicles from the plasma of elderly subjects and from senescent endothelial cells promote vascular calcification. Aging 9: 778-789. doi:10.18632/aging .101191

Anderson HC. 1995. Molecular biology of matrix vesicles. Clin Orthop Relat Res 314: 266-280. doi:10.1097/ 00003086-199505000-00034

Anderson HA, Englert R, Gursel I, Shacter E. 2002. Oxidative stress inhibits the phagocytosis of apoptotic cells that have externalized phosphatidylserine. Cell Death Differ 9: 616-625. doi:10.1038/sj.cdd.4401013

Barrere F, van Blitterswijk CA, de Groot K. 2006. Bone regeneration: Molecular and cellular interactions with calcium phosphate ceramics. Int J Nanomedicine 1: 317332.

Baughman JM, Perocchi F, Girgis HS, Plovanich M, BelcherTimme CA, Sancak Y, Bao XR, Strittmatter L, Goldberger O, Bogorad RL, et al. 2011. Integrative genomics identifies MCU as an essential component of the mitochondrial calcium uniporter. Nature 476: 341-345. doi:10.1038/na ture10234 
D. Proudfoot

Berridge MJ. 1997. Elementary and global aspects of calcium signalling. J Physiol 499: 291-306. doi:10.1113/jphysiol $.1997 . s p 021927$

Berridge MJ. 2017. Vitamin D deficiency accelerates ageing and age-related diseases: A novel hypothesis. J Physiol 595: 6825-6836. doi:10.1113/JP274887

Boonrungsiman S, Gentleman E, Carzaniga R, Evans ND, McComb DW, Porter AE, Stevens MM. 2012. The role of intracellular calcium phosphate in osteoblast-mediated bone apatite formation. Proc Natl Acad Sci 109: 1417014175. doi:10.1073/pnas.1208916109

Bootman MD, Chehab T, Bultynck G, Parys JB, Rietdorf K. 2018. The regulation of autophagy by calcium signals: Do we have a consensus? Cell Calcium 70: 32-46. doi:10 $.1016 /$ j.ceca.2017.08.005

Boström KI, Rajamannan NM, Towler DA. 2011. The regulation of valvular and vascular sclerosis by osteogenic morphogens. Circ Res 109: 564-577. doi:10.1161/CIRC RESAHA.110.234278

Brown EM. 1991. Extracellular $\mathrm{Ca}^{2+}$ sensing, regulation of parathyroid cell function, and role of $\mathrm{Ca}_{2}^{+}$and other ions as extracellular (first) messengers. Physiol Rev 71: 371411. doi:10.1152/physrev.1991.71.2.371

Bucay N, Sarosi I, Dunstan CR, Morony S, Tarpley J, Capparelli C, Scully S, Tan HL, Xu W, Lacey DL, et al. 1998. Osteoprotegerin-deficient mice develop early onset osteoporosis and arterial calcification. Genes Dev 12: 1260 1268. doi:10.1101/gad.12.9.1260

Cai Z, Li F, Gong W, Liu W, Duan Q, Chen C, Ni L, Xia Y, Cianflone K, Dong N, et al. 2013. Endoplasmic reticulum stress participates in aortic valve calcification in hypercholesterolemic animals. Arterioscler Thromb Vasc Biol 33: 2345-2354. doi:10.1161/ATVBAHA.112.300226

Carafoli E. 1991. The calcium pumping ATPase of the plasma membrane. Annu Rev Physiol 53: 531-547. doi:10 $.1146 /$ annurev.ph.53.030191.002531

Caramés B, Taniguchi N, Otsuki S, Blanco FJ, Lotz M. 2010. Autophagy is a protective mechanism in normal cartilage, and its aging-related loss is linked with cell death and osteoarthritis. Arthritis Rheum 62: 791-801. doi:10 $.1002 /$ art. 27305

Castronovo V, Bellahcene A. 1998. Evidence that breast cancer associated microcalcifications are mineralized malignant cells. Int J Oncol 12: 305-308. doi:10.3892/ijo.12.2 .305

Chen NX, Kircelli F, O’Neill KD, Chen X, Moe SM. 2010. Verapamil inhibits calcification and matrix vesicle activity of bovine vascular smooth muscle cells. Kidney Int 77: 436-442. doi:10.1038/ki.2009.481

Chen X, Li M, Chen D, Gao W, Guan JL, Komatsu M, Yin XM. 2012. Autophagy induced by calcium phosphate precipitates involves endoplasmic reticulum membranes in autophagosome biogenesis. PLoS ONE 7: e52347. doi:10.1371/journal.pone.0052347

Chen X, Khambu B, Zhang H, Gao W, Li M, Chen X, Yoshimori T, Yin XM. 2014. Autophagy induced by calcium phosphate precipitates targets damaged endosomes. J Biol Chem 289: 11162-11174. doi:10.1074/jbc.M113.531855

Chen NX, O'Neill KD, Moe SM. 2018. Matrix vesicles induce calcification of recipient vascular smooth muscle cells through multiple signaling pathways. Kidney Int 93: 343-354. doi:10.1016/j.kint.2017.07.019
Cheung HS, Devine TR, Hubbard W. 1997. Calcium phosphate particle induction of metalloproteinase and mitogenesis: Effect of particle sizes. Osteoarthritis Cartilage 5: 145-151. doi:10.1016/S1063-4584(97)80009-X

Cho I, Chang HJ, Ó Hartaigh B, Shin S, Sung JM, Lin FY, Achenbach S, Heo R, Berman DS, Budoff MJ, et al. 2015. Incremental prognostic utility of coronary CT angiography for asymptomatic patients based upon extent and severity of coronary artery calcium: Results from the COronary CT Angiography EvaluatioN For Clinical Outcomes InteRnational Multicenter (CONFIRM) study. Eur Heart J 36: 501-508. doi:10.1093/eurheartj/ehu358

Choi H, Srikanth S, Atti E, Pirih FQ, Nervina JM, Gwack Y, Tetradis S. 2018. Deletion of Orail leads to bone loss aggravated with aging and impairs function of osteoblast lineage cells. Bone Rep 8: 147-155. doi:10.1016/j.bonr .2018 .03 .007

Clarke B. 2008. Normal bone anatomy and physiology. Clin J Am Soc Nephrol 3: S131-S139. doi:10.2215/CJN .04151206

Clarke MC, Talib S, Figg NL, Bennett MR. 2010. Vascular smooth muscle cell apoptosis induces interleukin-1-directed inflammation: Effects of hyperlipidemia-mediated inhibition of phagocytosis. Circ Res 106: 363-372. doi:10 .1161/CIRCRESAHA.109.208389

Collin J, Gössl M, Matsuo Y, Cilluffo RR, Flammer AJ, Loeffler D, Lennon RJ, Simari RD, Spoon DB, Erbel R, et al. 2015. Osteogenic monocytes within the coronary circulation and their association with plaque vulnerability in patients with early atherosclerosis. Int J Cardiol 181: 5764. doi:10.1016/j.ijcard.2014.11.156

Costello JC, Rosenthal AK, Kurup IV, Masuda I, Medhora M, Ryan LM. 2011. Parallel regulation of extracellular ATP and inorganic pyrophosphate: Roles of growth factors, transduction modulators, and ANK. Connect Tissue Res 52: 139-146. doi:10.3109/03008207.2010.491928

Dai XY, Zhao MM, Cai Y, Guan QC, Zhao Y, Guan Y, Kong W, Zhu WG, Xu MJ, Wang X. 2013. Phosphate-induced autophagy counteracts vascular calcification by reducing matrix vesicle release. Kidney Int 83: 1042-1051. doi:10 $.1038 / \mathrm{ki} .2012 .482$

Dautova Y, Kozlova D, Skepper JN, Epple M, Bootman MD, Proudfoot D. 2014. Fetuin-A and albumin alter cytotoxic effects of calcium phosphate nanoparticles on human vascular smooth muscle cells. PLoS ONE 9: e97565. doi:10.1371/journal.pone.0097565

Dautova Y, Kapustin AN, Pappert K, Epple M, Okkenhaug H, Cook SJ, Shanahan CM, Bootman MD, Proudfoot D. 2018. Calcium phosphate particles stimulate interleukin$1 \beta$ release from human vascular smooth muscle cells: A role for spleen tyrosine kinase and exosome release. J Mol Cell Cardiol 115: 82-93. doi:10.1016/j.yjmcc.2017.12.007

DeMeo NN, Burgess JD, Blackburn PR, Gass JM, Richter J, Atwal HK, van Gerpen JA, Atwal PS. 2018. Co-occurrence of a novel PDGFRB variant and likely pathogenic variant in CASR in an individual with extensive intracranial calcifications and hypocalcaemia. Clin Case Rep 6: 813. doi:10.1002/ccr3.1265

Demer LL, Tintut Y. 2014. Inflammatory, metabolic, and genetic mechanisms of vascular calcification. Arterioscler Thromb Vasc Biol 34: 715-723. doi:10.1161/ATVBAHA .113 .302070 
Deneke T, Langner K, Grewe PH, Harrer E, Müller KM. 2001. Ossification in atherosclerotic carotid arteries. $Z$ Kardiol 90: 106-115. doi:10.1007/s003920170031

Derfus BA, Rachow JW, Mandel NS, Boskey AL, Buday M, Kushnaryov VM, Ryan LM. 1992. Articular cartilage vesicles generate calcium pyrophosphate dihydrate-like crystals in vitro. Arthritis Rheum 35: 231-240.

De Stefani D, Raffaello A, Teardo E, Szabò I, Rizzuto R. 2011. A forty-kilodalton protein of the inner membrane is the mitochondrial calcium uniporter. Nature 476: 336-340. doi:10.1038/nature 10230

Draeger A, Monastyrskaya K, Babiychuk EB. 2011. Plasma membrane repair and cellular damage control: The annexin survival kit. Biochem Pharmacol 81: 703-712. doi:10.1016/j.bcp.2010.12.027

Duan X, Zhou Y, Teng X, Tang C, Qi Y. 2009. Endoplasmic reticulum stress-mediated apoptosis is activated in vascular calcification. Biochem Biophys Res Commun 387: 694699. doi:10.1016/j.bbrc.2009.07.085

Duer MJ, Friščić T, Proudfoot D, Reid DG, Schoppet M, Shanahan CM, Skepper JN, Wise ER. 2008. Mineral surface in calcified plaque is like that of bone: Further evidence for regulated mineralization. Arterioscler Thromb Vasc Biol 28: 2030-2034. doi:10.1161/ATVBAHA.108 .172387

East DA, Campanella M. 2013. $\mathrm{Ca}^{2+}$ in quality control: An unresolved riddle critical to autophagy and mitophagy. Autophagy 9: 1710-1719. doi:10.4161/auto.25367

Erlinge D. 1998. Extracellular ATP: A growth factor for vascular smooth muscle cells. Gen Pharmacol 31: 1-8. doi:10 .1016/S0306-3623(97)00420-5

Ewence AE, Bootman M, Roderick HL, Skepper JN, McCarthy G, Epple M, Neumann M, Shanahan CM, Proudfoot D. 2008. Calcium phosphate crystals induce cell death in human vascular smooth muscle cells: A potential mechanism in atherosclerotic plaque destabilization. Circ Res 103: e28-e34. doi:10.1161/CIRCRESAHA.108.181305

Fader CM, Colombo MI. 2006. Multivesicular bodies and autophagy in erythrocyte maturation. Autophagy 2: 122-125. doi:10.4161/auto.2.2.2350

Farzaneh-Far A, Proudfoot D, Weissberg PL, Shanahan CM. 2000. Matrix Gla protein is regulated by a mechanism functionally related to the calcium-sensing receptor. Biochem Biophys Res Commun 277: 736-740. doi:10.1006/ bbrc.2000.3747

Farzaneh-Far A, Weissberg PL, Proudfoot D, Shanahan CM. 2001. Transcriptional regulation of matrix Gla protein. $Z$ Kardiol 90: 38-42. doi:10.1007/s003920170040

Fleckenstein-Grun G, Frey M, Thimm F, Hofgärtner W, Fleckenstein A. 1992. Calcium overload-An important cellular mechanism in hypertension and arteriosclerosis. Drugs 44: 23-30. doi:10.2165/00003495-19920044100005

Fleckenstein-Grün G, Thimm F, Czirfuzs A, Matyas S, Frey M. 1994. Experimental vasoprotection by calcium antagonists against calcium-mediated arteriosclerotic alterations. J Cardiovasc Pharmacol 24: S75-S84. doi:10 .1097/00005344-199406242-00012

Forster RE, Jurutka PW, Hsieh JC, Haussler CA, Lowmiller CL, Kaneko I, Haussler MR, Kerr Whitfield G. 2011. Vitamin D receptor controls expression of the anti-aging klotho gene in mouse and human renal cells. Biochem
Biophys Res Commun 414: 557-562. doi:10.1016/j.bbrc .2011.09.117

Frede A, Neuhaus B, Knuschke T, Wadwa M, Kollenda S, Klopfleisch R, Hansen W, Buer J, Bruder D, Epple M, et al. 2017. Local delivery of siRNA-loaded calcium phosphate nanoparticles abates pulmonary inflammation. Nanomedicine 13: 2395-2403. doi:10.1016/j.nano.2017.08.001

Ganote CE, Philipsborn DS, Chen E, Carone FA. 1975. Acute calcium nephrotoxicity. An electron microscopical and semiquantitative light microscopical study. Arch Pathol 99: 650-657.

Gao W, Ding WX, Stolz DB, Yin XM. 2008. Induction of macroautophagy by exogenously introduced calcium. Autophagy 4: 754-761. doi:10.4161/auto.6360

Gao W, Kang JH, Liao Y, Ding WX, Gambotto AA, Watkins SC, Liu YJ, Stolz DB, Yin XM. 2010. Biochemical isolation and characterization of the tubulovesicular LC3-positive autophagosomal compartment. J Biol Chem 285: 13711383. doi:10.1074/jbc.M109.054197

Goldberg HA, Warner KJ, Stillman MJ, Hunter GK. 1996. Determination of the hydroxyapatite-nucleating region of bone sialoprotein. Connect Tissue Res 35: 385-392. doi:10 $.3109 / 03008209609029216$

Gonzalo S, Kreienkamp R, Askjaer P. 2017. HutchinsonGilford Progeria syndrome: A premature aging disease caused by LMNA gene mutations. Ageing Res Rev 33: 18-29. doi:10.1016/j.arr.2016.06.007

Greger RF. 2000. Physiology and pathophysiology of calcium homeostasis. Z Kardiol 89: 4-8. doi:10.1007/s003 920070093

Gui T, Zhou G, Sun Y, Shimokado A, Itoh S, Oikawa K, Muragaki Y. 2012. MicroRNAs that target $\mathrm{Ca}^{2+}$ transporters are involved in vascular smooth muscle cell calcification. Lab Invest 92: 1250-1259. doi:10.1038/labinvest .2012 .85

Gunter TE, Zuscik MJ, Puzas JE, Gunter KK, Rosier RN. 1990. Cytosolic free calcium concentrations in avian growth plate chondrocytes. Cell Calcium 11: 445-457. doi:10.1016/0143-4160(90)90077-8

He G, George A. 2004. Dentin matrix protein 1 immobilized on type I collagen fibrils facilitates apatite deposition in vitro. J Biol Chem 279: 11649-11656. doi:10.1074/jbc .M309296200

Hessle L, Johnson KA, Anderson HC, Narisawa S, Sali A, Goding JW, Terkeltaub R, Millan JL. 2002. Tissue-nonspecific alkaline phosphatase and plasma cell membrane glycoprotein-1 are central antagonistic regulators of bone mineralization. Proc Natl Acad Sci 99: 9445-9449. doi:10 $.1073 /$ pnas.142063399

Hocking LJ, Whitehouse C, Helfrich MH. 2012. Autophagy: A new player in skeletal maintenance? J Bone Miner Res 27: 1439-1447. doi:10.1002/jbmr.1668

House SJ, Potier M, Bisaillon J, Singer HA, Trebak M. 2008. The non-excitable smooth muscle: Calcium signaling and phenotypic switching during vascular disease. Pflugers Arch 456: 769-785. doi:10.1007/s00424-008-0491-8

Hulten EA, Carbonaro S, Petrillo SP, Mitchell JD, Villines TC. 2011. Prognostic value of cardiac computed tomography angiography: A systematic review and meta-analysis. J Am Coll Cardiol 57: 1237-1247. doi:10.1016/j.jacc .2010 .10 .011 
D. Proudfoot

Hutcheson JD, Maldonado N, Aikawa E. 2014. Small entities with large impact: Microcalcifications and atherosclerotic plaque vulnerability. Curr Opin Lipidol 25: 327-332. doi:10.1097/MOL.0000000000000105

Hwang SY, Foley J, Numaga-Tomita T, Petranka JG, Bird GS Putney JW Jr. 2012. Deletion of Orail alters expression of multiple genes during osteoclast and osteoblast maturation. Cell Calcium 52: 488-500. doi:10.1016/j.ceca.2012 .10 .001

Iannotti JP, Brighton CT. 1989. Cytosolic ionized calcium concentration in isolated chondrocytes from each zone of the growth plate. JOrthop Res 7: 511-518. doi:10.1002/jor .1100070408

Jahnen-Dechent W, Schinke T, Trindl A, Müller-Esterl W, Sablitzky F, Kaiser S, Blessing M. 1997. Cloning and targeted deletion of the mouse fetuin gene. J Biol Chem 272: 31496-31503. doi:10.1074/jbc.272.50.31496

Jethwa SA, Leah EJ, Zhang Q, Bright NA, Oxley D, Bootman MD, Rudge SA, Wakelam MJ. 2016. Exosomes bind to autotaxin and act as a physiological delivery mechanism to stimulate LPA receptor signalling in cells. J Cell Sci 129: 3948-3957. doi:10.1242/jcs.184424

Jørgensen NR, Geist ST, Civitelli R, Steinberg TH. 1997. ATP- and gap junction-dependent intercellular calcium signaling in osteoblastic cells. J Cell Biol 139: 497-506. doi:10.1083/jcb.139.2.497

Kaplan FS, Xu M, Seemann P, Connor JM, Glaser DL, Carroll L, Delai P, Fastnacht-Urban E, Forman SJ, GillessenKaesbach G, et al. 2009. Classic and atypical fibrodysplasia ossificans progressiva (FOP) phenotypes are caused by mutations in the bone morphogenetic protein (BMP) type I receptor ACVR1. Hum Mutat 30: 379-390. doi:10.1002/humu.20868

Kapustin AN, Davies JD, Reynolds JL, McNair R, Jones GT, Sidibe A, Schurgers LJ, Skepper JN, Proudfoot D, Mayr M, et al. 2011. Calcium regulates key components of vascular smooth muscle cell-derived matrix vesicles to enhance mineralization. Circ Res 109: e1-e12. doi:10.1161/CIRC RESAHA.110.238808

Kapustin AN, Chatrou ML, Drozdov I, Zheng Y, Davidson SM, Soong D, Furmanik M, Sanchis P, De Rosales RT, Alvarez-Hernandez D, et al. 2015. Vascular smooth muscle cell calcification is mediated by regulated exosome secretion. Circ Res 116: 1312-1323. doi:10.1161/CIRCRE SAHA.116.305012

Kim KM. 1976. Calcification of matrix vesicles in human aortic valve and aortic media. Fed Proc 35: 156-162.

Kim KM. 1995. Apoptosis and calcification. Scanning Microsc 9: 1137-1175. discussion 1175-1138.

Kim KM, Trump BF. 1975. Amorphous calcium precipitations in human aortic valve. Calcif Tissue Res 18: 155-160. doi:10.1007/BF02546237

Kim KM, Herrera GA, Battarbee HD. 1999. Role of glutaraldehyde in calcification of porcine aortic valve fibroblasts. Am J Pathol 154: 843-852. doi:10.1016/S00029440(10)65331-X

Kirsch T, Nah HD, Shapiro IM, Pacifici M. 1997. Regulated production of mineralization-competent matrix vesicles in hypertrophic chondrocytes. J Cell Biol 137: 1149-1160. doi:10.1083/jcb.137.5.1149

Kockx MM, De Meyer GR, Muhring J, Jacob W, Bult H, Herman AG. 1998. Apoptosis and related proteins in different stages of human atherosclerotic plaques. Circulation 97: 2307-2315. doi:10.1161/01.CIR.97.23.2307

Kojima Y, Volkmer JP, McKenna K, Civelek M, Lusis AJ, Miller CL, Direnzo D, Nanda V, Ye J, Connolly AJ, et al. 2016. CD47-blocking antibodies restore phagocytosis and prevent atherosclerosis. Nature 536: 86-90. doi:10.1038/ nature 18935

Krebs J, Agellon LB, Michalak M. 2015. $\mathrm{Ca}^{2+}$ homeostasis and endoplasmic reticulum (ER) stress: An integrated view of calcium signaling. Biochem Biophys Res Commun 460: 114-121. doi:10.1016/j.bbrc.2015.02.004

Kreienkamp R, Croke M, Neumann MA, Bedia-Diaz G, Graziano S, Dusso A, Dorsett D, Carlberg C, Gonzalo S. 2016. Vitamin D receptor signaling improves Hutchinson-Gilford progeria syndrome cellular phenotypes. Oncotarget 7: 30018-30031. doi:10.18632/oncotarget.9065

Kuro-o M, Matsumura Y, Aizawa H, Kawaguchi H, Suga T, Utsugi T, Ohyama Y, Kurabayashi M, Kaname T, Kume E, et al. 1997. Mutation of the mouse klotho gene leads to a syndrome resembling ageing. Nature 390: 45-51. doi:10 $.1038 / 36285$

LeGeros RZ. 2001. Formation and transformation of calcium phosphates: Relevance to vascular calcification. $Z$ Kardiol 90: 116-124. doi:10.1007/s003920170032

Lehninger AL. 1970. Mitochondria and calcium ion transport. Biochem J 119: 129-138. doi:10.1042/bj1190129

Lemasters JJ, DiGuiseppi J, Nieminen AL, Herman B. 1987. Blebbing, free $\mathrm{Ca}^{2+}$ and mitochondrial membrane potential preceding cell death in hepatocytes. Nature 325: 7881. doi: $10.1038 / 325078 \mathrm{a} 0$

Lerman DA, Prasad S, Alotti N. 2015. Calcific aortic valve disease: Molecular mechanisms and therapeutic approaches. Eur Cardiol 10: 108-112. doi:10.15420/ecr .2015.10.2.108

Li GW, Xing WJ, Bai SZ, Hao JH, Guo J, Li HZ, Li HX, Zhang WH, Yang BF, Wu LY, et al. 2011. The calcium-sensing receptor mediates hypoxia-induced proliferation of rat pulmonary artery smooth muscle cells through MEK1/ ERK1,2 and PI3K pathways. Basic Clin Pharmacol Toxicol 108: $185-193$. doi:10.1111/j.1742-7843.2010.00639.x

Lieben L, Carmeliet G. 2012. The involvement of TRP channels in bone homeostasis. Front Endocrinol 3: 99. doi:10 .3389/fendo.2012.00099

Liu Y, Drozdov I, Shroff R, Beltran LE, Shanahan CM. 2013. Prelamin A accelerates vascular calcification via activation of the DNA damage response and senescence-associated secretory phenotype in vascular smooth muscle cells. Circ Res 112: e99-e109. doi:10.1161/CIRCRE SAHA.111.300543

Lu XL, Huo B, Chiang V, Guo XE. 2012. Osteocytic network is more responsive in calcium signaling than osteoblastic network under fluid flow. J Bone Miner Res 27: 563-574. doi:10.1002/jbmr.1474

Luo G, Ducy P, McKee MD, Pinero GJ, Loyer E, Behringer RR, Karsenty G. 1997. Spontaneous calcification of arteries and cartilage in mice lacking matrix GLA protein. Nature 386: 78-81. doi:10.1038/386078a0

Mahamid J, Sharir A, Gur D, Zelzer E, Addadi L, Weiner S. 2011. Bone mineralization proceeds through intracellular calcium phosphate loaded vesicles: A cryo-electron microscopy study. J Struct Biol 174: 527-535. doi:10.1016/j .jsb.2011.03.014 
Malis CD, Bonventre JV. 1986. Mechanism of calcium potentiation of oxygen free radical injury to renal mitochondria. A model for post-ischemic and toxic mitochondrial damage. J Biol Chem 261: 14201-14208.

Mallilankaraman K, Doonan P, Cárdenas C, Chandramoorthy HC, Müller M, Miller R, Hoffman NE, Gandhirajan RK, Molgo J, Birnbaum MJ, et al. 2012. MICU1 is an essential gatekeeper for MCU-mediated mitochondrial $\mathrm{Ca}^{2+}$ uptake that regulates cell survival. Cell 151: 630644. doi:10.1016/j.cell.2012.10.011

Marche P, Stepien O. 2000. Calcium antagonists and vascular smooth muscle cell reactivity. Z Kardiol 89: 140-144. doi:10.1007/s003920070114

Meier M, Weng LP, Alexandrakis E, Rüschoff J, Goeckenjan G. 2001. Tracheobronchial stenosis in Keutel syndrome. Eur Respir J 17: 566-569. doi:10.1183/09031936.01 .17305660

Melendez AJ, Tay HK. 2008. Phagocytosis: A repertoire of receptors and $\mathrm{Ca}_{2}{ }^{+}$as a key second messenger. Biosci Rep 28: 287-298. doi:10.1042/BSR20080082

Mendoza FJ, Martinez-Moreno J, Almaden Y, RodriguezOrtiz ME, Lopez I, Estepa JC, Henley C, Rodriguez M, Aguilera-Tejero E. 2011. Effect of calcium and the calcimimetic AMG 641 on matrix-Gla protein in vascular smooth muscle cells. Calcif Tissue Int 88: 169-178. doi:10.1007/s00223-010-9442-4

Messenger SW, Woo SS, Sun Z, Martin TFJ. 2018. $\mathrm{A} \mathrm{Ca}^{2+}$. stimulated exosome release pathway in cancer cells is reg ulated by Munc13-4. J Cell Biol 217: 2877-2890. doi:10 $.1083 /$ jcb.201710132

Montezano AC, Zimmerman D, Yusuf H, Burger D, Chignalia AZ, Wadhera V, van Leeuwen FN, Touyz RM. 2010. Vascular smooth muscle cell differentiation to an osteogenic phenotype involves TRPM7 modulation by magnesium. Hypertension 56: 453-462. doi:10.1161/HYPER TENSIONAHA.110.152058

Moore ED, Etter EF, Philipson KD, Carrington WA, Fogarty KE, Lifshitz LM, Fay FS. 1993. Coupling of the $\mathrm{Na}^{+} / \mathrm{Ca}^{2+}$ exchanger, $\mathrm{Na}^{+} / \mathrm{K}^{+}$pump and sarcoplasmic reticulum in smooth muscle. Nature 365: 657-660. doi:10.1038/ $365657 \mathrm{a} 0$

Morony S, Tintut Y, Zhang Z, Cattley RC, Van G, Dwyer D, Stolina M, Kostenuik PJ, Demer LL. 2008. Osteoprotegerin inhibits vascular calcification without affecting atherosclerosis in $1 \mathrm{dlr}^{-/-}$mice. Circulation 117: 411-420.

Morrell AE, Brown GN, Robinson ST, Sattler RL, Baik AD, Zhen G, Cao X, Bonewald LF, Jin W, Kam LC, et al. 2018. Mechanically induced $\mathrm{Ca}^{2+}$ oscillations in osteocytes release extracellular vesicles and enhance bone formation. Bone Res 6. doi:10.1038/s41413-018-0007-x

Motoyama S, Ito H, Sarai M, Kondo T, Kawai H, Nagahara Y, Harigaya H, Kan S, Anno H, Takahashi H, et al. 2015. Plaque characterization by coronary computed tomography angiography and the likelihood of acute coronary events in mid-term follow-up. J Am Coll Cardiol 66: 337-346. doi:10.1016/j.jacc.2015.05.069

Motro M, Shemesh J. 2001. Calcium channel blocker nifedipine slows down progression of coronary calcification in hypertensive patients compared with diuretics. Hypertension 37: 1410-1413. doi:10.1161/01.HYP.37.6.1410

Motro M, Shemesh J, Grossman E. 2001. Coronary benefits of calcium antagonist therapy for patients with hyperten- sion. Curr Opin Cardiol 16: 349-355. doi:10.1097/ 00001573-200111000-00006

Munroe PB, Olgunturk RO, Fryns JP, Van Maldergem L, Ziereisen F, Yuksel B, Gardiner RM, Chung E. 1999. Mutations in the gene encoding the human matrix Gla protein cause Keutel syndrome. Nat Genet 21: 142-144. doi: $10.1038 / 5102$

Murakami T, Saito A, Hino S, Kondo S, Kanemoto S, Chihara K, Sekiya H, Tsumagari K, Ochiai K, Yoshinaga K, et al. 2009. Signalling mediated by the endoplasmic reticulum stress transducer OASIS is involved in bone formation. Nat Cell Biol 11: 1205-1211. doi:10.1038/ncb1963

Nakatani S, Mano H, Ryanghyok IM, Shimizu J, Wada M. 2006. Excess magnesium inhibits excess calcium-induced matrix-mineralization and production of matrix gla protein (MGP) by ATDC5 cells. Biochem Biophys Res Commun 348: 1157-1162. doi:10.1016/j.bbrc.2006.07.180

Negishi-Koga T, Takayanagi H. 2009. $\mathrm{Ca}^{2+}$-NFATc1 signaling is an essential axis of osteoclast differentiation. Immunol Rev 231: 241-256. doi:10.1111/j.1600-065X.2009 .00821.x

New SE, Goettsch C, Aikawa M, Marchini JF, Shibasaki M, Yabusaki K, Libby P, Shanahan CM, Croce K, Aikawa E. 2013. Macrophage-derived matrix vesicles: An alternative novel mechanism for microcalcification in atherosclerotic plaques. Circ Res 113: 72-77. doi:10.1161/CIRCRESAHA .113 .301036

Nitschke Y, Hartmann S, Torsello G, Horstmann R, Seifarth H, Weissen-Plenz G, Rutsch F. 2011. Expression of NPP1 is regulated during atheromatous plaque calcification. J Cell Mol Med 15: 220-231.

Ohanian J, Gatfield KM, Ward DT, Ohanian V. 2005. Evidence for a functional calcium-sensing receptor that modulates myogenic tone in rat subcutaneous small arteries. Am J Physiol Heart Circ Physiol 288: H1756H1762. doi:10.1152/ajpheart.00739.2004

Olszak IT, Poznansky MC, Evans RH, Olson D, Kos C, Pollak MR, Brown EM, Scadden DT. 2000. Extracellular calcium elicits a chemokinetic response from monocytes in vitro and in vivo. J Clin Invest 105: 1299-1305. doi:10 $.1172 /$ JCI9799

Orrenius S, Zhivotovsky B, Nicotera P. 2003. Regulation of cell death: The calcium-apoptosis link. Nat Rev Mol Cell Biol 4: 552-565. doi:10.1038/nrm1150

Orth SR, Nobiling R, Bönisch S, Ritz E. 1996. Inhibitory effect of calcium channel blockers on human mesangial cell growth: Evidence for actions independent of L-type $\mathrm{Ca}^{2+}$ channels. Kidney Int 49: 868-879. doi:10.1038/ki .1996 .120

Otsuka K, Fukuda S, Tanaka A, Nakanishi K, Taguchi H, Yoshikawa J, Shimada K, Yoshiyama M. 2013. Napkinring sign on coronary CT angiography for the prediction of acute coronary syndrome. JACC Cardiovasc Imaging 6: 448-457. doi:10.1016/j.jcmg.2012.09.016

Panda DK, Bai X, Sabbagh Y, Zhang Y, Zaun HC, Karellis A, Koromilas AE, Lipman ML, Karaplis AC. 2018. Defective interplay between mTORC1 activity and endoplasmic reticulum stress-unfolded protein response in uremic vascular calcification. Am J Physiol Renal Physiol 314: F1046-F1061. doi:10.1152/ajprenal.00350.2017

Pei DD, Sun JL, Zhu CH, Tian FC, Jiao K, Anderson MR, Yiu C, Huang C, Jin CX, Bergeron BE, et al. 2018. Contribu- 
D. Proudfoot

tion of mitophagy to cell-mediated mineralization: Revisiting a 50-year-old conundrum. Adv Sci 5: 1800873. doi:10.1002/advs.201800873

Pele LC, Haas CT, Hewitt RE, Robertson J, Skepper J, Brown A, Hernandez-Garrido JC, Midgley PA, Faria N, Chappell $\mathrm{H}$, et al. 2017. Synthetic mimetics of the endogenous gastrointestinal nanomineral: Silent constructs that trap macromolecules for intracellular delivery. Nanomedicine 13: 619-630. doi:10.1016/j.nano.2016.07.008

Pillai ICL, Li S, Romay M, Lam L, Lu Y, Huang J, Dillard N, Zemanova M, Rubbi L, Wang Y, et al. 2017. Cardiac fibroblasts adopt osteogenic fates and can be targeted to attenuate pathological heart calcification. Cell Stem Cell 20: 218-232.e15. doi:10.1016/j.stem.2016.10.005

Price PA, Faus SA, Williamson MK. 1998. Warfarin causes rapid calcification of the elastic lamellae in rat arteries and heart valves. Arterioscler Thromb Vasc Biol 18: 1400 1407. doi:10.1161/01.ATV.18.9.1400

Proudfoot D, Dautova Y. 2013. https://www.flickr.com/ photos/bhforguk/8703368927 [accessed April 23, 2019].

Proudfoot D, Skepper JN, Hegyi L, Bennett MR, Shanahan CM, Weissberg PL. 2000. Apoptosis regulates human vascular calcification in vitro: Evidence for initiation of vascular calcification by apoptotic bodies. Circ Res 87: 10551062. doi:10.1161/01.RES.87.11.1055

Proudfoot D, Davies JD, Skepper JN, Weissberg PL, Shanahan CM. 2002. Acetylated low-density lipoprotein stimulates human vascular smooth muscle cell calcification by promoting osteoblastic differentiation and inhibiting phagocytosis. Circulation 106: 3044-3050. doi:10.1161/ 01.CIR.0000041429.83465.41

Raggio CL, Boyan BD, Boskey AL. 1986. In vivo hydroxyapatite formation induced by lipids. J Bone Miner Res 1: 409-415. doi:10.1002/jbmr.5650010505

Ragnauth CD, Warren DT, Liu Y, McNair R, Tajsic T, Figg N, Shroff R, Skepper J, Shanahan CM. 2010. Prelamin A acts to accelerate smooth muscle cell senescence and is a novel biomarker of human vascular aging. Circulation 121: 2200-2210. doi:10.1161/CIRCULATIONAHA.109.9020 56

Reddy A, Caler EV, Andrews NW. 2001. Plasma membrane repair is mediated by $\mathrm{Ca}^{2+}$-regulated exocytosis of lysosomes. Cell 106: 157-169. doi:10.1016/S0092-8674(01) 00421-4

Reynolds JL, Joannides AJ, Skepper JN, McNair R, Schurgers LJ, Proudfoot D, Jahnen-Dechent W, Weissberg PL, Shanahan CM. 2004. Human vascular smooth muscle cells undergo vesicle-mediated calcification in response to changes in extracellular calcium and phosphate concentrations: A potential mechanism for accelerated vascular calcification in ESRD. J Am Soc Nephrol 15: 2857-2867. doi:10.1097/01.ASN.0000141960.01035.28

Rimessi A, Bonora M, Marchi S, Patergnani S, Marobbio CM, Lasorsa FM, Pinton P. 2013. Perturbed mitochondrial $\mathrm{Ca}^{2+}$ signals as causes or consequences of mitophagy induction. Autophagy 9: 1677-1686. doi:10.4161/auto .24795

Robinson LJ, Mancarella S, Songsawad D, Tourkova IL, Barnett JB, Gill DL, Soboloff J, Blair HC. 2012. Gene disruption of the calcium channel Orail results in inhibition of osteoclast and osteoblast differentiation and impairs skel- etal development. Lab Invest 92: 1071-1083. doi:10.1038/ labinvest.2012.72

Roijers RB, Dutta RK, Cleutjens JP, Mutsaers PH, de Goeij JJ, van der Vusse GJ. 2008. Early calcifications in human coronary arteries as determined with a proton microprobe. Anal Chem 80: 55-61. doi:10.1021/ac0706628

Rutsch F, Nitschke Y, Terkeltaub R. 2011. Genetics in arterial calcification: Pieces of a puzzle and cogs in a wheel. Circ Res 109: 578-592. doi:10.1161/CIRCRESAHA.111 .247965

Ryan LM, Cheung HS, McCarty DJ. 1981. Release of pyrophosphate by normal mammalian articular hyaline and fibrocartilage in organ culture. Arthritis Rheum 24: 15221527. doi:10.1002/art.1780241211

Ryan LM, Kurup IV, Derfus BA, Kushnaryov VM. 1992. ATP-induced chondrocalcinosis. Arthritis Rheum 35: 1520-1525. doi:10.1002/art.1780351216

Safiulina D, Kuum M, Choubey V, Gogichaishvili N, Liiv J, Hickey MA, Cagalinec M, Mandel M, Zeb A, Liiv M, et al. 2019. Miro proteins prime mitochondria for Parkin translocation and mitophagy. $E M B O J$ 38: e99384. doi:10 .15252/embj.201899384

Saito A, Hino S, Murakami T, Kanemoto S, Kondo S, Saitoh M, Nishimura R, Yoneda T, Furuichi T, Ikegawa S, et al. 2009. Regulation of endoplasmic reticulum stress response by a BBF2H7-mediated Sec23a pathway is essential for chondrogenesis. Nat Cell Biol 11: 1197-1204. doi:10.1038/ncb1962

Sarkar S, Korolchuk V, Renna M, Winslow A, Rubinsztein DC. 2009. Methodological considerations for assessing autophagy modulators: A study with calcium phosphate precipitates. Autophagy 5: 307-313. doi:10.4161/auto.5.3 .7664

Savina A, Furlán M, Vidal M, Colombo MI. 2003. Exosome release is regulated by a calcium-dependent mechanism in K562 cells. J Biol Chem 278: 20083-20090. doi:10 .1074/jbc.M301642200

Schmid K, McSharry WO, Pameijer CH, Binette JP. 1980. Chemical and physicochemical studies on the mineral deposits of the human atherosclerotic aorta. Atherosclerosis 37: 199-210. doi:10.1016/0021-9150(80)90005-2

Schurgers LJ, Cranenburg EC, Vermeer C. 2008. Matrix Glaprotein: The calcification inhibitor in need of vitamin $\mathrm{K}$ Thromb Haemost 100: 593-603. doi:10.1160/TH08-020087

Schurgers LJ, Joosen IA, Laufer EM, Chatrou ML, Herfs M, Winkens MH, Westenfeld R, Veulemans V, Krueger T, Shanahan CM, et al. 2012. Vitamin K-antagonists accelerate atherosclerotic calcification and induce a vulnerable plaque phenotype. PLoS ONE 7: e43229.

Scimeca M, Giannini E, Antonacci C, Pistolese CA, Spagnoli LG, Bonanno E. 2014. Microcalcifications in breast cancer: An active phenomenon mediated by epithelial cells with mesenchymal characteristics. BMC Cancer 14: 286. doi:10.1186/1471-2407-14-286

Settembre C, Arteaga-Solis E, McKee MD, de Pablo R, Al Awqati Q, Ballabio A, Karsenty G. 2008. Proteoglycan desulfation determines the efficiency of chondrocyte autophagy and the extent of FGF signaling during endochondral ossification. Genes Dev 22: 2645-2650. doi:10 $.1101 /$ gad. 1711308 
Shanahan CM, Furmanik M. 2017. Endoplasmic reticulum stress in arterial smooth muscle cells: A novel regulator of vascular disease. Curr Cardiol Rev 13: 94-105. doi:10 .2174/1573403X12666161014094738

Shanahan CM, Cary NR, Salisbury JR, Proudfoot D, Weissberg PL, Edmonds ME. 1999. Medial localization of mineralization-regulating proteins in association with Monckeberg's sclerosis: Evidence for smooth muscle cell-mediated vascular calcification. Circulation 100: 2168-2176. doi:10.1161/01.CIR.100.21.2168

Shanahan CM, Crouthamel MH, Kapustin A, Giachelli CM. 2011. Arterial calcification in chronic kidney disease: Key roles for calcium and phosphate. Circ Res 109: 697-711. doi:10.1161/CIRCRESAHA.110.234914

Shapiro IM, Landis WJ, Risbud MV. 2015. Matrix vesicles: Are they anchored exosomes? Bone 79: 29-36. doi:10 .1016/j.bone.2015.05.013

Shimada T, Kakitani M, Yamazaki Y, Hasegawa H, Takeuchi Y, Fujita T, Fukumoto S, Tomizuka K, Yamashita T. 2004 Targeted ablation of Fgf23 demonstrates an essential physiological role of FGF23 in phosphate and vitamin D metabolism. J Clin Invest 113: 561-568. doi:10.1172/ JCI200419081

Shoshan-Barmatz V, Nahon-Crystal E, Shteinfer-Kuzmine A, Gupta R. 2018. VDAC1, mitochondrial dysfunction, and Alzheimer's disease. Pharmacol Res 131: 87-101. doi:10.1016/j.phrs.2018.03.010

Shroff RC, McNair R, Figg N, Skepper JN, Schurgers L, Gupta A, Hiorns M, Donald AE, Deanfield J, Rees L, et al. 2008. Dialysis accelerates medial vascular calcification in part by triggering smooth muscle cell apoptosis. Circulation 118: 1748-1757. doi:10.1161/CIRCULATION AHA.108.783738

Shroff RC, McNair R, Skepper JN, Figg N, Schurgers LJ, Deanfield J, Rees L, Shanahan CM. 2010. Chronic mineral dysregulation promotes vascular smooth muscle cell adaptation and extracellular matrix calcification. J Am Soc Nephrol 21: 103-112. doi:10.1681/ASN.2009060640

Sucher NJ, Awobuluyi M, Choi YB, Lipton SA. 1996. NMDA receptors: From genes to channels. Trends Pharmacol Sci 17: 348-355. doi:10.1016/S0165-6147(96)80008-3

Swiader A, Nahapetyan H, Faccini J, D’Angelo R, Mucher E, Elbaz M, Boya P, Vindis C. 2016. Mitophagy acts as a safeguard mechanism against human vascular smooth muscle cell apoptosis induced by atherogenic lipids. Oncotarget 7: 28821-28835. doi:10.18632/oncotarget.8936

Szegezdi E, Logue SE, Gorman AM, Samali A. 2006. Mediators of endoplasmic reticulum stress-induced apoptosis EMBO Rep 7: 880-885. doi:10.1038/sj.embor.7400779

Tomazic BB. 2001. Physiochemical principles of cardiovascular calcification. $Z$ Kardiol 90: 68-80. doi:10.1007/ s003920170046
Tsien RW, Ellinor PT, Horne WA. 1991. Molecular diversity of voltage-dependent $\mathrm{Ca}^{2+}$ channels. Trends Pharmacol Sci 12: 349-354. doi:10.1016/0165-6147(91)90595-J

Tyson KL, Reynolds JL, McNair R, Zhang Q, Weissberg PL, Shanahan CM. 2003. Osteo/chondrocytic transcription factors and their target genes exhibit distinct patterns of expression in human arterial calcification. Arterioscler Thromb Vasc Biol 23: 489-494. doi:10.1161/01.ATV .0000059406 .92165 .31

Vengrenyuk Y, Carlier S, Xanthos S, Cardoso L, Ganatos P, Virmani R, Einav S, Gilchrist L, Weinbaum S. 2006. A hypothesis for vulnerable plaque rupture due to stressinduced debonding around cellular microcalcifications in thin fibrous caps. Proc Natl Acad Sci 103: 14678-14683. doi:10.1073/pnas.0606310103

Wamhoff BR, Bowles DK, McDonald OG, Sinha S, Somlyo AP, Somlyo AV, Owens GK. 2004. L-type voltage-gated $\mathrm{Ca}^{2+}$ channels modulate expression of smooth muscle differentiation marker genes via a Rho kinase/myocardin/SRF-dependent mechanism. Circ Res 95: 406-414. doi:10.1161/01.RES.0000138582.36921.9e

Wang W, Kirsch T. 2002. Retinoic acid stimulates annexinmediated growth plate chondrocyte mineralization. J Cell Biol 157: 1061-1069. doi:10.1083/jcb.200203014

Wang W, Xu J, Kirsch T. 2003. Annexin-mediated $\mathrm{Ca}^{2+}$ influx regulates growth plate chondrocyte maturation and apoptosis. J Biol Chem 278: 3762-3769. doi:10 .1074/jbc.M208868200

Wang C, Li Y, Shi L, Ren J, Patti M, Wang T, de Oliveira JR, Sobrido MJ, Quintans B, Baquero M, et al. 2012. Mutations in SLC20A2 link familial idiopathic basal ganglia calcification with phosphate homeostasis. Nat Genet 44: 254-256. doi:10.1038/ng.1077

Warren DT, Tajsic T, Porter LJ, Minaisah RM, Cobb A, Jacob A, Rajgor D, Zhang QP, Shanahan CM. 2015. Nesprin-2dependent ERK1/2 compartmentalisation regulates the DNA damage response in vascular smooth muscle cell ageing. Cell Death Differ 22: 1540-1550. doi:10.1038/ cdd. 2015.12

Whelan LC, Morgan MP, McCarthy GM. 2005. Basic calcium phosphate crystals as a unique therapeutic target in osteoarthritis. Front Biosci 10: 530-541. doi:10.2741/1549

Xu J, Camfield R, Gorski SM. 2018. The interplay between exosomes and autophagy-Partners in crime. J Cell Sci 131: jcs215210. doi:10.1242/jcs.215210

Zebboudj AF, Shin V, Boström K. 2003. Matrix GLA protein and BMP-2 regulate osteoinduction in calcifying vascular cells. J Cell Biochem 90: 756-765. doi:10.1002/jcb.10669

Zhu Y, Ji JJ, Yang R, Han XQ, Sun XJ, Ma WQ, Liu NF. 2019. Lactate accelerates calcification in VSMCs through suppression of BNIP3-mediated mitophagy. Cell Signal 58: 53-64. doi:10.1016/.j.cellsig.2019.03.006 


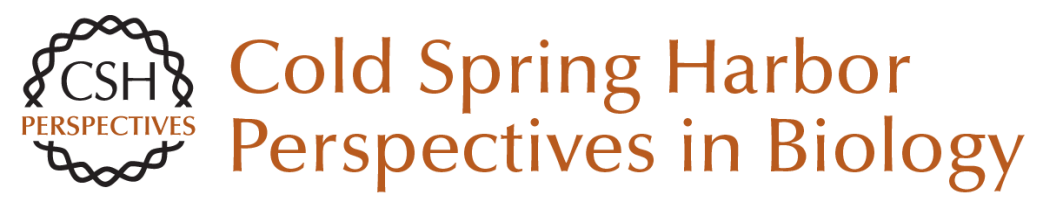

\section{Calcium Signaling and Tissue Calcification}

Diane Proudfoot

Cold Spring Harb Perspect Biol 2019; doi: 10.1101/cshperspect.a035303 originally published online May 28, 2019

\section{Subject Collection Calcium Signaling}

The Endoplasmic Reticulum-Plasma Membrane Junction: A Hub for Agonist Regulation of $\mathrm{Ca}^{2+}$ Entry

Hwei Ling Ong and Indu Suresh Ambudkar

Calcium-Handling Defects and Neurodegenerative Disease

Sean Schrank, Nikki Barrington and Grace E. Stutzmann

Lysosomal $\mathrm{Ca}^{2+}$ Homeostasis and Signaling in Health and Disease

Emyr Lloyd-Evans and Helen Waller-Evans

\section{$\mathrm{Ca}^{2+}$ Signaling in Exocrine Cells}

Malini Ahuja, Woo Young Chung, Wei-Yin Lin, et al.

Functional Consequences of Calcium-Dependent Synapse-to-Nucleus Communication: Focus on Transcription-Dependent Metabolic Plasticity Anna M. Hagenston, Hilmar Bading and Carlos Bas-Orth

Identifying New Substrates and Functions for an Old Enzyme: Calcineurin Jagoree Roy and Martha S. Cyert

Fundamentals of Cellular Calcium Signaling: A Primer

Martin D. Bootman and Geert Bultynck
Primary Active $\mathrm{Ca}^{2+}$ Transport Systems in Health and Disease Jialin Chen, Aljona Sitsel, Veronick Benoy, et al.

Signaling through $\mathrm{Ca}^{2+}$ Microdomains from Store-Operated CRAC Channels Pradeep Barak and Anant B. Parekh

Structural Insights into the Regulation of $\mathrm{Ca}^{2+}$ /Calmodulin-Dependent Protein Kinase II (CaMKII) Moitrayee Bhattacharyya, Deepti Karandur and John Kuriyan

Store-Operated Calcium Channels: From Function to Structure and Back Again Richard S. Lewis

Bcl-2-Protein Family as Modulators of $\mathrm{IP}_{3}$

Receptors and Other Organellar $\mathrm{Ca} 2+$ Channels Hristina Ivanova, Tim Vervliet, Giovanni Monaco, et al.

Calcium Signaling in Cardiomyocyte Function Guillaume Gilbert, Kateryna Demydenko, Eef Dries, et al.

Cytosolic $\mathrm{Ca}^{2+}$ Buffers Are Inherently $\mathrm{Ca}^{2+}$ Signal Modulators Beat Schwaller

For additional articles in this collection, see http://cshperspectives.cshlp.org/cgi/collection/

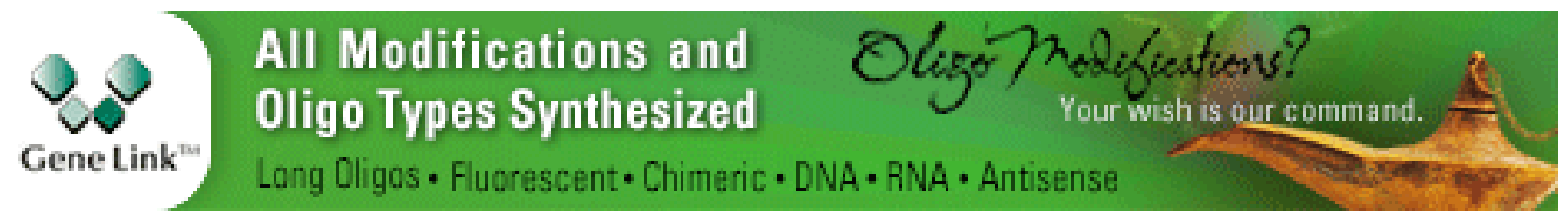


Role of Two-Pore Channels in Embryonic Development and Cellular Differentiation Sarah E. Webb, Jeffrey J. Kelu and Andrew L. Miller

\section{Organellar Calcium Handling in the Cellular \\ Reticular Network}

Wen-An Wang, Luis B. Agellon and Marek Michalak

For additional articles in this collection, see http://cshperspectives.cshlp.org/cgi/collection/

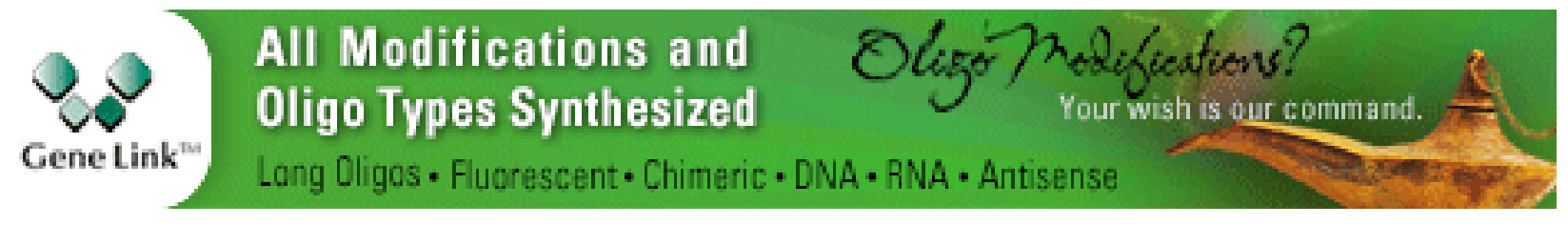

Copyright @ 2019 Cold Spring Harbor Laboratory Press; all rights reserved 